\title{
Levels of Minor and Trace Elements of Some Commercial Fruit Juices and Syrup Produced in Artisanal and Semi-Industrial Units in Benin Republic
}

\author{
Alassane A. K. Youssao ${ }^{1,2}$, Magloire A. N. Gbaguidi ${ }^{1,2}$, Léonce Dovonon ${ }^{1,2}$, Oriol Baltrons ${ }^{3}$, Fabienne Seby ${ }^{3}$, Mathilde \\ Monperus $^{4}$, Mickael Saizonou ${ }^{1,2}$, Henri H. Soclo ${ }^{1,2}$, Olivier Donard ${ }^{3,4}$ \\ ${ }^{1}$ Unité de Recherche de Recherche en Ecotoxicologie et Etude de Qualité/Laboratoire d'Etude et de Recherche en Chimie \\ Appliquée/Ecole Polytechnique d'Abomey-Calavi/Université d'Abomey-Calavi, 01 BP 2009 Cotonou, Benin \\ ${ }^{2}$ Unité de Recherche en Ecotoxicologie et Eude de Qualité (UREEQ)/ Ecole Polytechnique d'Abomey-Calavi, Bénin \\ ${ }^{3}$ Ultra Trace Analysis Aquitaine (UT2A)/Université de Pau et des Pays de l'Adour (UPPA), France \\ ${ }^{4}$ Laboratoire de Chimie Analytique Bio-inorganique et Environnement/ Université de Pau et des Pays de l'Adour (UPPA) \\ - Institut Pluridisciplinaire de Recherche sur l'Environnement et les Matériaux (IPREM - UMR 5254) HELIOPARC - 2 , \\ Avenue du Président Pierre Angot 64053 PAU Cedex 9, France
}

Correspondence: Alassane Youssao Abdou Karim, Ecole Polytechnique d'Abomey-Calavi, Université d'Abomey-Calavi, 01 BP 2009 Cotonou, Benin. Email: youssaoalassane@ gmail.com

Received: October 10, 2018 Accepted: November 7, 2018 Online Published: November 19, 2018

doi:10.5539/ijc.v10n4p68

URL: https://doi.org/10.5539/ijc.v10n4p68

\begin{abstract}
Fruit juices have been gaining interest in recent years for their contributions of minerals and other essential vitamins. But, with the development of intensive agriculture massively using pesticides and mineral fertilizers, the risk of contamination of these juices is high along the production chain. In this study, we evaluated the concentrations of arsenic (As), cadmium $(\mathrm{Cd})$, berrylium $(\mathrm{Be})$, aluminium $(\mathrm{Al})$, strontium $(\mathrm{Sr})$, tin $(\mathrm{Sn})$, barium $(\mathrm{Ba})$, mercury $(\mathrm{Hg})$, thallium $(\mathrm{Tl})$, lead $(\mathrm{Pb})$, thorium $(\mathrm{Th})$, uranium $(\mathrm{U})$ for 92 commercial samples of pineapple juice, cocktail of pineapple and watermelon and pineapple syrup of Benin and France using Inductively Coupled Plasma-Source Mass Spectrometry (ICP-MS). The concentrations vary in the following ranges: As $<\mathrm{QL}$ at $39.3 \mathrm{ppb}, \mathrm{Cd}<\mathrm{QL}$ at $0.7 \mathrm{ppb}, \mathrm{Be}$ $<\mathrm{QL}$ at $0.59 \mathrm{ppb}, \mathrm{Al} 26.4 \mathrm{ppb}$ at $30620 \mathrm{ppb}, \mathrm{Sr} 130 \mathrm{ppb}$ at $4049 \mathrm{ppb}, \mathrm{Sn}<\mathrm{QL}$ at $43 \mathrm{ppb}$, Ba $42 \mathrm{ppb}$ at $1582 \mathrm{ppb}, \mathrm{Hg}<\mathrm{QL}$ at $31.7 \mathrm{ppb}, \mathrm{Tl}<\mathrm{QL}$ at $21.3 \mathrm{ppb}, \mathrm{Pb}<\mathrm{QL}$ at $608 \mathrm{ppb}$, Th<QL at $24.7 \mathrm{ppb} \mathrm{ppb}$ and $\mathrm{U}<\mathrm{QL}$ at $1.04 \mathrm{ppb}$. Se, Ag and $\mathrm{Pt}$ have concentrations below the quantification limit $(<\mathrm{QL})$. The levels of $\mathrm{Ba}, \mathrm{Hg}$ and $\mathrm{Pb}$ exceeded the norms for some samples. The presence of aluminum, arsenic and cadmium in the tested samples of fruit juices can be toxic since they have no nutritional value, and hence may be treated as potential contaminants in these beverages. The classification of concentration levels of metallic contaminants reveals two main groups, the minor and the trace elements. These results make it possible to classify the contaminants in the decreasing order of the concentrations in the following way: $\mathrm{Al}>\mathrm{Sr}>$ $\mathrm{Ba}>\mathrm{Pb}>\mathrm{Sn}>\mathrm{Tl}>\mathrm{As}>\mathrm{Th}>\mathrm{Hg}>\mathrm{Cd}>\mathrm{Be}>\mathrm{U}$. The average concentrations' levels of trace elements are generally in accordance with the levels obtained for French pineapple juices chosen as reference, national and international standards for the quality of beverages.
\end{abstract}

Keyword: metallic contaminants, pineapple, watermelon, syrup, juice, ICP-MS

\section{Introduction}

\subsection{Contamination Factors}

According to Sodjinou and al. (2011) quoted by Hotegni and al. (2015), the increase of the pineapple production in Benin Republic is more dependent on the expansion of the planted areas than on the improvement of yield in the sense that during the period from 2000 to 2010, the yield of pineapple production increased only $19 \%$ from 44 tons/ha to 52 tons/ha with a production rising from 51151 tons to 222223 tons during the same period, an increase of $334 \%$. According to Arouna and Afommasse (2005) quoted by Hotegni and al. (2012 and 2015), in the technical itineraries of production of pineapple in Benin, the phytosanitary treatment and the use of synthetic fertilizers is systematic. It should also be noted that in place of the recommended equipment, pineapple producers use cans of 20 or 25 liters for the treatment of floral induction which is not without negative consequences on the treatment and even on the health of the producers. However, several factors can contribute to the observed variations in element concentrations, including the availability of elements for uptake by plants (strictly related to soil characteristics, mineral composition and soil $\mathrm{pH}$ ), 
agricultural practices and plant nutrients. The procedures applied during the growth of the fruiting plants (the application of fertilizers and irrigation, water and climatic conditions), and finally, the variation of treatments at the plant, in addition to the type and maturity of the fruits at harvest (Paula and al., 2014). The use of synthetic chemicals, such as fertilizers or pesticides to maintain or improve soil fertility, is known to have a significant effect on micronutrient concentrations in fruit juices. The use of agrochemicals, for instance, insecticides or fungicides used during the growth of fruit plants, is responsible for reducing the nutritional quality and safety of these products due to an increased risk of human exposure to toxic metals (eg, $\mathrm{Cd}$ and $\mathrm{Pb}$ ) (Williams and al. 2010; Szymczycha-Madeja and al. 2014; Kiliç and al. 2015; Lopez and al. 2002; Tufuor and al. 2011).

\subsection{Choice of Mineralisation Method of Fruit Juces's}

In this study, we mineralized the samples taken to destroy organic matter due to the high viscosity and high solid content; direct analysis of fruit juices under these conditions often causes many non-spectral difficulties (mainly matrix effects) and spectral interferences in spectrometric measurements. Spectrochemical methods are used for the determination of elements in fruit juices after wet mineralization, eg, with atomic flame absorption spectrometry (FAAS) (Krejpcio and al. 2005), graphite furnace atomic absorption spectrometry (GF- AAS) (Oliveira and al. 2005; Liu and al. 1999), inductively coupled plasma optical emission spectrometry (ICP-OES) (Simpkins and al. 2000; WHO, 1996) and inductively coupled plasma source mass spectrometry (ICP-MS) (Lai and al. 2016). This can be avoided when fruit juice samples are mineralized before analysis (Liu and al. 1999; Lai and al. 2016). Tables 1 and 2 summarize the literature review on analytical methods and concentration ranges of elements in fruit juices.

Table 1. Methods of analysis of elements in fruit juices

\begin{tabular}{|c|c|c|c|c|}
\hline $\mathrm{N}^{\circ}$ & Auteurs et année & Matrices & Méthodes & Eléments \\
\hline 1 & Akan and al., 2010 & Juice & AAS & $\mathrm{Cr}, \mathrm{Mn}, \mathrm{Co}, \mathrm{Ni}, \mathrm{Cu}, \mathrm{Zn}, \mathrm{Cd}, \mathrm{Sn}, \mathrm{Pb}$ \\
\hline 2 & Chmara and al., 1996 & Pineapple juice and nectars. & AAS & $\mathrm{Ca}, \mathrm{Mg}, \mathrm{Cu}, \mathrm{Fe}, \mathrm{Mn}, \mathrm{Zn}$ \\
\hline 3 & Beattie and al., 2000 & pineapple juice & FAAS and EPR & Mn \\
\hline 4 & Francisco and al., 2015 & Fruit Juices & GFAAS and FAAS & $\begin{array}{l}\text { GFAAS }(\mathrm{Cd}, \mathrm{Cr}, \mathrm{Pb}, \mathrm{Ni}) \text { and FAAS } \\
(\mathrm{Zn}, \mathrm{Fe})\end{array}$ \\
\hline 5 & Santos Froes and al., 2009 & Fruit Juices & ICP OES & $\begin{array}{l}\mathrm{Al}, \mathrm{Cu}, \mathrm{Fe}, \mathrm{Mn}, \mathrm{Zn}, \mathrm{Ni}, \mathrm{Cd}, \mathrm{Pb}, \mathrm{Sn}, \\
\mathrm{Cr}, \mathrm{Co}, \mathrm{Ba}\end{array}$ \\
\hline 6 & $\begin{array}{l}\text { Szymczycha-Madeja and } \\
\text { al., } 2014\end{array}$ & Fruit Juices & $\begin{array}{l}\text { XRFS, INAA, ICP-OES, } \\
\text { ICP-MS, FAAS, GF, AAS }\end{array}$ & $\begin{array}{l}\mathrm{Mg}, \mathrm{Ca}, \mathrm{V}, \mathrm{Cr}, \mathrm{Mn}, \mathrm{Fe}, \mathrm{Ni}, \mathrm{Cu}, \mathrm{Zn}, \\
\mathrm{Se}, \mathrm{Cd}, \mathrm{Al}, \mathrm{Sr}, \mathrm{Mo}, \mathrm{Sn}, \mathrm{Ba}, \mathrm{Hg}, \mathrm{Pb}\end{array}$ \\
\hline 7 & $\begin{array}{l}\text { Szymczycha-Madeja and } \\
\text { al., } 2013\end{array}$ & Commercial fruit juices & ICP-OES & $\begin{array}{l}\mathrm{Mg}, \mathrm{Ca}, \mathrm{V}, \mathrm{Cr}, \mathrm{Mn}, \mathrm{Fe}, \mathrm{Ni}, \mathrm{Cu}, \mathrm{Zn}, \\
\mathrm{Se}, \mathrm{Cd}, \mathrm{Al}, \mathrm{Sr}, \mathrm{Mo}, \mathrm{Sn}, \mathrm{Ba}, \mathrm{Hg}, \mathrm{Pb}\end{array}$ \\
\hline 8 & Tormen and al., 2011 & Commercial fruit juices & ICP-MS & $\begin{array}{l}\mathrm{Ca}, \mathrm{V}, \mathrm{Mn}, \mathrm{Fe}, \mathrm{Co}, \mathrm{Ni}, \mathrm{Cu}, \mathrm{Zn}, \mathrm{Cd} \text {, } \\
\mathrm{Sr}, \mathrm{Mo}, \mathrm{Pb}\end{array}$ \\
\hline
\end{tabular}

Table 2. Concentration ranges of elements (ppm) in fruit juices according to the authors

\begin{tabular}{|c|c|c|c|c|c|c|c|c|c|c|c|}
\hline Elements & $\mathrm{Mg}$ & $\mathrm{Ca}$ & V & $\mathrm{Cr}$ & $\mathrm{Mn}$ & $\mathrm{Fe}$ & Co & $\mathrm{Ni}$ & \multicolumn{2}{|c|}{$\mathrm{Cu}$} & $\mathrm{Zn}$ \\
\hline Authors $\mathrm{N}^{\circ}$ & $\begin{array}{c}2,6 \\
7\end{array}$ & $2,6,7,8$ & 6,8 & $\begin{array}{c}1,4,5 \\
6,7\end{array}$ & $\begin{array}{c}1,2,3,5,6 \\
7,8\end{array}$ & $\begin{array}{c}2,4,5,6 \\
\quad 7,8\end{array}$ & $1,5,8$ & $\begin{array}{l}4,5,6 \\
7,8\end{array}$ & \multicolumn{2}{|c|}{$\begin{array}{c}1,2,5,6 \\
7,8\end{array}$} & $\begin{array}{c}1,2,4,5,6, \\
7,8\end{array}$ \\
\hline $\begin{array}{l}\text { Concentrations } \\
(\mathrm{ppm})\end{array}$ & $\begin{array}{c}7- \\
750 \\
\end{array}$ & $\begin{array}{l}0.14- \\
980.1 \\
\end{array}$ & $\begin{array}{c}0.005- \\
0.052 \\
\end{array}$ & $\begin{array}{l}\mathrm{ND}- \\
2.767 \\
\end{array}$ & $0.06-23$ & $\begin{array}{c}0.009- \\
179.2 \\
\end{array}$ & $\begin{array}{l}\text { ND - } \\
0.004 \\
\end{array}$ & $\begin{array}{l}0.04- \\
73.37 \\
\end{array}$ & \multicolumn{2}{|c|}{ ND -0.49} & $0.04-545.9$ \\
\hline Elements & & $\mathrm{Se}$ & $\mathrm{Cd}$ & $\mathrm{Al}$ & $\mathrm{Sr}$ & Mo & $\mathrm{Sn}$ & & & $\mathrm{Hg}$ & $\mathrm{Pb}$ \\
\hline Authors $\mathrm{N}^{\circ}$ & & 6 & $\begin{array}{c}1,4,5,6,7, \\
8\end{array}$ & $5,6,7$ & $6,7,8$ & 6,8 & $1,5,6$ & & & 6 & $6,7,8$ \\
\hline $\begin{array}{l}\text { Concentrations } \\
(\mathrm{ppm})\end{array}$ & & $\begin{array}{c}0.014 \\
-0.015 \\
\end{array}$ & $0-0.012$ & $\begin{array}{l}0- \\
4.2 \\
\end{array}$ & $\begin{array}{c}0.088- \\
0.88 \\
\end{array}$ & $\begin{array}{r}0.0487 \\
-0.049 \\
\end{array}$ & $\begin{array}{c}0- \\
0.45 \\
\end{array}$ & & & $\begin{array}{l}0 . \\
3\end{array}$ & $\begin{array}{c}\mathrm{ND}- \\
0.24 \\
\end{array}$ \\
\hline
\end{tabular}

Auteurs $\mathrm{N}^{\circ}=$ authors indicated in the table $1 ; \mathrm{ND}=$ Not detected 1.3 Levels of juice contaminants

According to Szymczycha-Madeja and al. (2014) the concentrations of chemical elements in pineapple juices vary in the ranges shown below in Table 3. 
Table 3. Concentrations (in $\mu \mathrm{g} . \mathrm{mL}^{-1}$ ) of different elements in pineapple juices

\begin{tabular}{|c|c|c|c|c|c|c|c|c|}
\hline Elements & $\mathrm{Al}$ & $\mathrm{Ba}$ & $\mathrm{Cd}$ & $\mathrm{Co}$ & $\mathrm{Cr}$ & Mo & $\mathrm{Pb}$ & $\mathrm{Rb}$ \\
\hline Concentrations & ND-4.2 & $0.04-0.11$ & ND-0.012 & ND-0.004 & ND-0.017 & 0.049 & ND-0.24 & $0.45-1.1$ \\
\hline Elements & $\mathrm{Se}$ & $\mathrm{Sn}$ & $\mathrm{Sr}$ & $\mathrm{Ti}$ & $\mathrm{V}$ & $\mathrm{Zr}$ & & \\
\hline Concentrations & $0.014-0.015$ & ND-0.45 & $0.088-0.62$ & 0.30 & 0.005 & 0.2 & & \\
\hline
\end{tabular}

Source: Szymczycha-Madeja and al. (2014); ND= Not detected

\subsection{Hypotheses}

The underlying hypothesis of this study was that the quality juices produced in Benin is affected by the use of fertizers, pesticides, transport conditions, juice extraction and conditioning conditions etc. The verification of this hypothesis will be done through the analysis of the conformity with the national and international standards of quality of the water and food of Codex alimentarus (table 4) and according to the literature review.

In international legislation concerning micronutrients in foods, environment or occupational health, most regulations are based on the total content of elements and are often indicated as maximum or guideline limits. However, several techniques are developed for research and determination of metallic and metalloid contaminants in foods and beverages (Akman and al., 2007, Varadi and al., 2007). Specifically, most contaminants are not regulated, but juices can be compared to drinking water. The WHO guidelines for drinking water quality, updated in 2006, are the benchmark for safe drinking water. The legislation varies from one country to another, table 4 below summarizes the standards of WHO (2006) and that of Benin, Brazil, Codex Alimentarius (Codex, 1997) and Canadian one.

Table 4. Some quality standards for water and beverages

\begin{tabular}{|c|c|c|c|c|c|}
\hline \multirow[b]{2}{*}{ Contaminants } & \multicolumn{5}{|c|}{ Standards (ppb) } \\
\hline & Benin* & Brazilian Legislation & Codex Alimentarus & WHO (2006) & Canadian $* *$ \\
\hline As & 50 & - & - & 10 & 50 \\
\hline $\mathrm{Se}$ & 10 & - & - & 10 & 10 \\
\hline $\mathrm{Ag}$ & - & - & - & No guide value & 50 \\
\hline $\mathrm{Al}$ & - & - & - & 200 & - \\
\hline $\mathrm{Ba}$ & 1000 & - & - & 700 & 1000 \\
\hline $\mathrm{Be}$ & - & - & - & No guide value & - \\
\hline $\mathrm{Cd}$ & 5 & 200 & 50 & 3 & 10 \\
\hline $\mathrm{Cr}$ & & & & 50 & \\
\hline $\mathrm{Hg}$ & 1 & & & 1 & \\
\hline $\mathrm{Pb}$ & 50 & 200 & 50 & 10 & 50 \\
\hline $\mathrm{Pt}$ & - & - & - & - & - \\
\hline $\mathrm{Sn}$ & - & 250 & 150 & No guide value & \\
\hline $\mathrm{Sr}$ & - & - & - & - & - \\
\hline Th & - & - & - & - & - \\
\hline $\mathrm{Tl}$ & - & - & - & 50 & - \\
\hline $\mathrm{U}$ & - & - & - & 15 & 5000 \\
\hline
\end{tabular}

* physico-chemical standards for water intended for human consumption

** maximum permissible concentration for drinking water

\section{Material and Methods}

\subsection{Juices Sampling}

Juice sampling was carried out in variable numbers per unit in order to take into account various factors of variability such as the environment of growing of pineapple, juices production environment, the dates of manufacture or of expiry, the packaging of products etc. The environment of the growing area, the soil and the place of production of the juices 
were taken into account in terms of rays compared to the city of Cotonou taken as origin $(0 \mathrm{Km})$. In practice, eighty-five (85) juice bottles (kept in glass containers of varying size and volume) were randomly sampled from about twenty juice producers located primarily near the growing areas of the pineapple (Figure 1). It counted 69 bottles of 33cl, $15 \mathrm{of} 50 \mathrm{cl}$ and 1 of $50 \mathrm{cl}$ high and of gray color. The dates of storage from production to laboratory analysis are also variable, as are the colors of the bottle packaging, of which there are 30 green bottles, 54 colorless bottles and 1 gray bottle. It should be noted here that pineapple products for export mainly consist of pineapple juice. For the analyses, a bottle of pineapple syrup was taken from a processing unit. Table 5 summarizes and describes the different samples analyzed per processing unit. The samples are in variable numbers per unit according to the different criteria observed such as the place and dates of manufacture, the nature of the juice (cocktail or pineapple juice), the species of pineapple fruit used (Sugarloaf, Smooth Cayenne etc.). Basing on the self-regulatory principles of researchers in research ethics, we opted for the non-disclosure of unit names or their marks which will be abbreviated using the three-letter initials (Table 5) and the corresponding samples will be distinguished by numerical indices on these abbreviated names.

Table 5. Presentation of the samples with their identification codes or Codec

\begin{tabular}{llc}
\hline City/country & NS & sample identification names \\
\hline ABOMEY & 7 & $\mathrm{JUA}_{1}-\mathrm{JUA}_{6}, \mathrm{SYR}$ \\
AKASSATO & 6 & $\mathrm{BRA}_{1}-\mathrm{BRA}_{6}$, \\
ALLADA & 13 & $\mathrm{CHA}_{1}-\mathrm{CHA}_{6}, \mathrm{OJA}_{1}-\mathrm{OJA}_{5}, \mathrm{TRO}_{1}-\mathrm{TRO}_{2}$ \\
AVAKPA & 9 & $\mathrm{SAN}_{1}-\mathrm{SAN}_{9}$ \\
CALAVI & 8 & $\mathrm{ALA}_{1}-\mathrm{ALA}_{2}, \mathrm{PAS}_{1}-\mathrm{PAS}_{6}$ \\
COME & 6 & $\mathrm{JUV}_{1}-\mathrm{JUV}_{6}$ \\
COTONOU & 7 & $\mathrm{VIP}_{1}-\mathrm{VIP}_{7}$ \\
EKPE & 6 & $\mathrm{ALO}_{1}-\mathrm{ALO}_{6}$ \\
FRANCE & 6 & $\mathrm{FRU}_{1}-\mathrm{FRU}_{6}$ \\
LOGBOZOUKPA & 6 & $\mathrm{JAF}_{1}-\mathrm{JNN}_{2}-\mathrm{INN}_{2}, \mathrm{VIB}_{1}-\mathrm{VIB}_{2}$ \\
PORTO-NOVO & 9 & $\mathrm{FRE}_{4}-\mathrm{FRE}_{5}, \mathrm{LAS}_{2}, \mathrm{JUD}_{1}-\mathrm{JUD}_{3}$ \\
SEKOU & 3 & $\mathrm{JUS}_{3}$ \\
ZE & 6 & $\mathrm{VIT1}_{2}-\mathrm{VIT}_{6}$ \\
TOTAL & 92 & \\
\hline NS: N Nber & & \\
\hline
\end{tabular}

NS.: Number of samples

Once collected, these bottles of juice and syrup are conveyed to the laboratory for investigations of chemical contaminants, which are detected and measured out by appropriate analysis techniques. The Codec or sample code is the identification number of each sample and the code is its acronym derived from the name of the processing unit to which a serial number is associated (Table 5). 


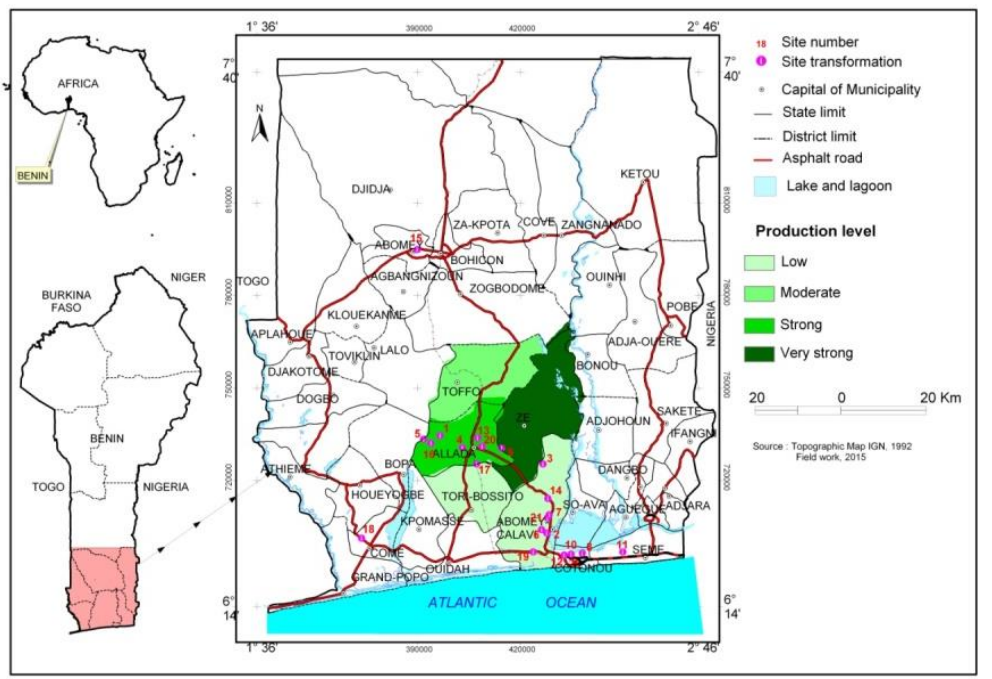

Figure 1. Location of processing units and growing areas of pineapple

\subsection{Choice of Method of Mineralization and Quantification of Samples}

We adopted conventional wet digestion in open systems by using DigiPrep digestion blocks for the decomposition of fruit juice samples with concentrated nitric acid $\left(\mathrm{HNO}_{3}\right)$ and hydrogen peroxide $\left(\mathrm{H}_{2} \mathrm{O}_{2}\right)$ at $30 \%$ (Szymczycha-Madeja and al. 2013; Santos Froes and al. 2009). To succeed in this, $2 \mathrm{ml}$ of ultra-pure $\mathrm{HNO}_{3}$ and $1 \mathrm{ml}$ of hydrogen peroxide were added to $2 \mathrm{ml}$ of juice samples in a Teflon container, closed untightly to let the vapors escape. The entire system was put in a programmable oven with two temperature stages $\left(45^{\circ}\right.$ and $\left.90^{\circ}\right)$. This feature of DigiPrep allowed the samples to be progressively brought to $45^{\circ} \mathrm{C}$ for $20 \mathrm{~min}$ and then held at this temperature for $40 \mathrm{~min}$ and then progressively brought to $90^{\circ} \mathrm{C}$ for $30 \mathrm{~min}$ and finally maintained at this temperature for $160 \mathrm{~min}$.

\subsection{Criteria for Validation of the Analytical Method}

The validation of the method consisted in evaluating: the linearity through the calibration (external and internal), the repeatability and the reproducibility, the limits of detection (LD) and of quantification (QL). To do this, standard certified mixed reference solutions of the desired elements are prepared in the range of 0 to $100 \mathrm{ppb}$ and injected. The mass spectra $\mathrm{m} / \mathrm{z}$ are determined and the external and internal calibration curves are plotted with the slopes, the coefficients of determination $\mathrm{R}^{2}$ and the ordinates at the origin. The results of the repeatability tests are presented in Table 7. The coefficients of variation \% CV are determined in each case. MRC certified water standards are digested under the same conditions; which allowed us to obtain good recovery rates for the chemical elements recorded with recovery rates between $80 \%$ and 105\% maximum except for zinc and cadmium with SRM SLRS-5 (table 6). 
Table 6. Recovery rates and concentrations $( \pm \mathrm{sd})$ of metals in reference materials in $\mu \mathrm{g} . \mathrm{L}^{-1}$

\begin{tabular}{|c|c|c|c|c|c|c|}
\hline \multirow[b]{2}{*}{ Analyte } & \multicolumn{3}{|c|}{ SRM NIST 1640a } & \multicolumn{3}{|c|}{ SRM SLRS-5 } \\
\hline & $\begin{array}{c}\text { Certified value } \\
\qquad(\mu \mathrm{g} / \mathrm{L})\end{array}$ & $\begin{array}{l}\text { Sample value } \\
\qquad(\mu \mathrm{g} / \mathrm{L})\end{array}$ & $\begin{array}{c}\text { Recovery } \\
(\%)\end{array}$ & $\begin{array}{l}\text { Certified value } \\
\qquad(\mu \mathrm{g} / \mathrm{L})\end{array}$ & $\begin{array}{l}\text { Sample value } \\
\qquad(\mu \mathrm{g} / \mathrm{L})\end{array}$ & $\begin{array}{c}\text { Recovery } \\
(\%)\end{array}$ \\
\hline $\mathrm{Be}$ & $3.026 \pm 0.028$ & $2.938 \pm 0.080$ & 97.1 & $0.005^{*}$ & $0.005 \pm 0.001$ & 100.0 \\
\hline $\mathrm{Al}$ & $53.0 \pm 1.8$ & $54.3 \pm 3.1$ & 102.5 & $49.5 \pm 5.0$ & $42.8 \pm 1.1$ & 86.0 \\
\hline V & $15.05 \pm 0.25$ & $12.16 \pm 0.32$ & 80.8 & $0.317 \pm 0.033$ & $0.284 \pm 0.003$ & 89.6 \\
\hline $\mathrm{Cr}$ & $40.54 \pm 0.30$ & $38.20 \pm 0.09$ & 94.2 & $0.208 \pm 0.023$ & $0.108 \pm 0.005$ & 51.9 \\
\hline $\mathrm{Mn}$ & $40.39 \pm 0.36$ & $39.05 \pm 1.31$ & 94.4 & $4.33 \pm 0.18$ & $4.37 \pm 0.09$ & 100.9 \\
\hline Co & $20.24 \pm 0.24$ & $18.97 \pm 0.26$ & 93.7 & $0.05^{*}$ & $0.05 \pm 0.01$ & 100.0 \\
\hline $\mathrm{Ni}$ & $25.32 \pm 0.14$ & $25.33 \pm 0.44$ & 100.0 & $0.476 \pm 0.064$ & $0.471 \pm 0.020$ & 98.9 \\
\hline $\mathrm{Cu}$ & $85.75 \pm 0.51$ & $87.40 \pm 1.36$ & 101.9 & $17.4 \pm 1.3$ & $19.7 \pm 0.4$ & 113.2 \\
\hline $\mathrm{Zn}$ & $55.64 \pm 0.35$ & $53.23 \pm 1.25$ & 95.7 & $0.845 \pm 0.095$ & $1.90 \pm 0.05$ & 224.9 \\
\hline As & $8.075 \pm 0.070$ & $7.190 \pm 0.332$ & 89.0 & $0.413 \pm 0.039$ & $0.412 \pm 0.015$ & 99.8 \\
\hline $\mathrm{Se}$ & $20.13 \pm 0.17$ & $19.16 \pm 1.41$ & 95.2 & - & - & - \\
\hline Mo & $45.60 \pm 0.61$ & $45.74 \pm 0.11$ & 100.3 & $0.27 \pm 0.04$ & $0.20 \pm 0.01$ & 74.1 \\
\hline $\mathrm{Ag}$ & $8.081 \pm 0.046$ & $9.370 \pm 0.251$ & 116.0 & - & - & - \\
\hline $\mathrm{Cd}$ & $3.992 \pm 0.074$ & $3.711 \pm 0.15$ & 93.0 & $0.0060 \pm 0.0014$ & $0.0083 \pm 0.0014$ & 138.3 \\
\hline $\mathrm{Ba}$ & $151.80 \pm 0.83$ & $146.66 \pm 1.38$ & 96.6 & $14.0 \pm 0.5$ & $14.0 \pm 0.1$ & 100.0 \\
\hline $\mathrm{Ca}^{* *}$ & - & - & - & $10.5 \pm 0.4$ & $10.2 \pm 0.3$ & 97.1 \\
\hline $\mathrm{Tl}$ & $1.619 \pm 0.016$ & $1.571 \pm 0.011$ & 97.0 & - & - & - \\
\hline $\mathrm{Pb}$ & $12.101 \pm 0.050$ & $11.927 \pm 0.122$ & 98.6 & $0.081 \pm 0.006$ & $0.072 \pm 0.002$ & 88.9 \\
\hline $\mathrm{Mg}^{* *}$ & - & - & - & $2.54 \pm 0.16$ & $2.59 \pm 0.08$ & 102.0 \\
\hline $\mathrm{U}$ & $25.35 \pm 0.27$ & $24.12 \pm 0.09$ & 95.1 & $0.093 \pm 0.006$ & $0.092 \pm 0.001$ & 98.9 \\
\hline $\mathrm{Fe}$ & $36.8 \pm 1.8$ & $28.2 \pm 0.6$ & 76.7 & $91.2 \pm 5.8$ & $80.3 \pm 2.8$ & 88.0 \\
\hline $\mathrm{Sr}$ & $126.03 \pm 0.91$ & $110.10 \pm 0.73$ & 87.4 & $53.6 \pm 1.3$ & $52.9 \pm 0.5$ & 98.7 \\
\hline
\end{tabular}

Note: concentrations are given with the same number of significant figures found in the certificate of analysis of the SRM

*Values not certified in the SRM; given for information only

*** Concentration reported in $\mathrm{mg} \mathrm{L}^{-1}$

\subsection{Analytical Method}

A Perkin Elmer ELAN DRC device equipped with a nebulizer was used with a Meinhart silica cyclone chamber for continuous spraying and nebulization. The operating conditions were optimized using an 8-level standard aqueous solution (for calibration of the apparatus) containing: $0 ; 0.05 ; 0.1 ; 0.5 ; 1 ; 5 ; 20$ and $100 \mathrm{ppb}$ and internal standards for the control of isotope intensities. The internal standards used are indium (In), bismuth (Bi) and scandium ( $\mathrm{Sc}$ ) of concentrations $5 \mathrm{ppb}$. Two types of reference materials (SRM NIST 1640a and SRM SLRS-5) were used to determine coverage percentages. 
Table 7. Repeatability test results

\begin{tabular}{|c|c|c|c|c|c|c|c|c|c|c|c|c|}
\hline \multirow[b]{2}{*}{ Samp } & \multicolumn{12}{|c|}{ Concentrations in elements (ppb) } \\
\hline & As & $\mathrm{Cd}$ & $\mathrm{Be}$ & $\mathrm{Al}$ & $\mathrm{Sr}$ & $\mathrm{Sn}$ & $\mathrm{Ba}$ & $\mathrm{Hg}$ & $\mathrm{T} 1$ & $\mathrm{~Pb}$ & Th & $\mathrm{U}$ \\
\hline CHA4a & $1.06 \pm 0.21$ & $<\mathrm{QL}$ & $0.067 \pm 0.010$ & $5052 \pm 221$ & $671 \pm 5$ & $21.2 \pm 0.1$ & $86.2 \pm 0.6$ & $<\mathrm{QL}$ & $0.13 \pm 0.01$ & $9.03 \pm 0.11$ & $2.43 \pm 0.01$ & $0.076 \pm 0.002$ \\
\hline CHA $4 \mathrm{~b}$ & $0.93 \pm 0.03$ & $<\mathrm{QL}$ & $0.063 \pm 0.008$ & $5074 \pm 250$ & $663 \pm 5$ & $18.3 \pm 0.3$ & $84.6 \pm 1.2$ & $<\mathrm{QL}$ & $0.14 \pm 0.01$ & $9.00 \pm 0.11$ & $2.67 \pm 0.04$ & $0.065 \pm 0.002$ \\
\hline $\mathrm{CHA} 4 \mathrm{c}$ & $<\mathrm{QL}$ & $<\mathrm{QL}$ & $0.056 \pm 0.011$ & $5158 \pm 230$ & $669 \pm 5$ & $16.9 \pm 0.2$ & $84.7 \pm 0.9$ & $<Q L$ & $0.14 \pm 0.01$ & $9.05 \pm 0.03$ & $2.53 \pm 0.06$ & $0.064 \pm 0.001$ \\
\hline JAF1a & $<\mathrm{QL}$ & $0.61 \pm 0.05$ & $0.070 \pm 0.016$ & $138 \pm 5$ & $816 \pm 16$ & $6.88 \pm 0.07$ & $292 \pm 4$ & $<\mathrm{QL}$ & $0.60 \pm 0.01$ & $0.35 \pm 0.01$ & $2.53 \pm 0.06$ & $0.069 \pm 0.004$ \\
\hline JAF $1 \mathrm{~b}$ & $<\mathrm{QL}$ & $0.61 \pm 0.06$ & $0.092 \pm 0.012$ & $148 \pm 9$ & $801 \pm 7$ & $6.11 \pm 0.09$ & $287 \pm 3$ & $<\mathrm{QL}$ & $0.59 \pm 0.03$ & $0.39 \pm 0.01$ & $2.12 \pm 0.02$ & $0.066 \pm 0.004$ \\
\hline JAF 1c & $<\mathrm{QL}$ & $0.57 \pm 0.08$ & $0.079 \pm 0.008$ & $135 \pm 7$ & $796 \pm 9$ & $4.83 \pm 0.05$ & $286 \pm 1$ & $<\mathrm{QL}$ & $0.60 \pm 0.01$ & $0.26 \pm 0.01$ & $1.87 \pm 0.01$ & $0.062 \pm 0.007$ \\
\hline JUA1a & $<\mathrm{QL}$ & $<\mathrm{QL}$ & $0.15 \pm 0.02$ & $913 \pm 54$ & $649 \pm 1$ & $9.17 \pm 0.05$ & $218 \pm 1$ & $<\mathrm{QL}$ & $1.14 \pm 0.02$ & $3.63 \pm 0.02$ & $1.72 \pm 0.02$ & $0.037 \pm 0.002$ \\
\hline JUA1b & $<\mathrm{QL}$ & $<\mathrm{QL}$ & $0.18 \pm 0.03$ & $911 \pm 35$ & $645 \pm 7$ & $12.8 \pm 0.4$ & $217 \pm 2$ & $<\mathrm{QL}$ & $1.13 \pm 0.01$ & $3.64 \pm 0.02$ & $1.78 \pm 0.03$ & $0.036 \pm 0.004$ \\
\hline JUA1c & $<\mathrm{QL}$ & $<\mathrm{QL}$ & $0.16 \pm 0.03$ & $899 \pm 46$ & $650 \pm 7$ & $7.92 \pm 0.05$ & $219 \pm 3$ & $<\mathrm{QL}$ & $1.14 \pm 0.03$ & $3.77 \pm 0.07$ & $1.84 \pm 0.04$ & $0.044 \pm 0.006$ \\
\hline LASa & $<\mathrm{QL}$ & $<\mathrm{QL}$ & $0.086 \pm 0.021$ & $3043 \pm 93$ & $1106 \pm 15$ & $6.95 \pm 0.07$ & $119 \pm 2$ & $<\mathrm{QL}$ & $1.52 \pm 0.05$ & $23.1 \pm 0.3$ & $1.58 \pm 0.05$ & $0.072 \pm 0.004$ \\
\hline LASb & $<\mathrm{QL}$ & $<\mathrm{QL}$ & $0.088 \pm 0.017$ & $3014 \pm 123$ & $1112 \pm 12$ & $5.97 \pm 0.08$ & $118 \pm 1$ & $<\mathrm{QL}$ & $1.50 \pm 0.04$ & $22.9 \pm 0.1$ & $1.54 \pm 0.09$ & $0.073 \pm 0.006$ \\
\hline LASc & $<\mathrm{QL}$ & $<\mathrm{QL}$ & $0.076 \pm 0.005$ & $2999 \pm 128$ & $1119 \pm 9$ & $7.26 \pm 0.12$ & $119 \pm 2$ & $<\mathrm{QL}$ & $1.50 \pm 0.03$ & $22.1 \pm 0.1$ & $1.48 \pm 0.06$ & $0.074 \pm 0.007$ \\
\hline OJA1a & $1.06 \pm 0.21$ & $<\mathrm{QL}$ & $0.067 \pm 0.010$ & $5052 \pm 221$ & $671 \pm 5$ & $21.2 \pm 0.1$ & $86.2 \pm 0.6$ & $<\mathrm{QL}$ & $0.13 \pm 0.01$ & $9.03 \pm 0.11$ & $2.43 \pm 0.01$ & $0.076 \pm 0.002$ \\
\hline OJA1b & $0.93 \pm 0.03$ & $<\mathrm{QL}$ & $0.063 \pm 0.008$ & $5074 \pm 250$ & $663 \pm 5$ & $18.3 \pm 0.3$ & $84.6 \pm 1.2$ & $<\mathrm{QL}$ & $0.14 \pm 0.01$ & $9.00 \pm 0.11$ & $2.67 \pm 0.04$ & $0.065 \pm 0.002$ \\
\hline OJA1c & $<\mathrm{QL}$ & $<\mathrm{QL}$ & $0.056 \pm 0.011$ & $5158 \pm 230$ & $669 \pm 5$ & $16.9 \pm 0.2$ & $84.7 \pm 0.9$ & $<\mathrm{QL}$ & $0.14 \pm 0.01$ & $9.05 \pm 0.03$ & $2.53 \pm 0.06$ & $0.064 \pm 0.001$ \\
\hline VIB1a & $<\mathrm{QL}$ & $0.46 \pm 0.07$ & $0.027 \pm 0.004$ & $154 \pm 5$ & $313 \pm 6$ & $10.5 \pm 0.1$ & $266 \pm 2$ & $<\mathrm{QL}$ & $0.20 \pm 0.01$ & $1.47 \pm 0.03$ & $1.98 \pm 0.08$ & $0.051 \pm 0.004$ \\
\hline VIB1b & $<\mathrm{QL}$ & $0.46 \pm 0.08$ & $0.034 \pm 0.017$ & $161 \pm 9$ & $314 \pm 4$ & $10.0 \pm 0.2$ & $281 \pm 4$ & $<\mathrm{QL}$ & $0.19 \pm 0.02$ & $1.48 \pm 0.03$ & $1.87 \pm 0.04$ & $0.050 \pm 0.002$ \\
\hline VIB1c & $<\mathrm{QL}$ & $0.42 \pm 0.07$ & $0.038 \pm 0.009$ & $161 \pm 6$ & $306 \pm 4$ & $11.3 \pm 0.1$ & $276 \pm 2$ & $<\mathrm{QL}$ & $0.19 \pm 0.01$ & $1.40 \pm 0.03$ & $2.01 \pm 0.02$ & $0.049 \pm 0.005$ \\
\hline VIP1a & $<\mathrm{QL}$ & $<\mathrm{QL}$ & $0.073 \pm 0.016$ & $130 \pm 5$ & $730 \pm 10$ & $8.93 \pm 0.06$ & $138 \pm 1$ & $<\mathrm{QL}$ & $1.49 \pm 0.02$ & $2.95 \pm 0.01$ & $2.38 \pm 0.01$ & $0.051 \pm 0.003$ \\
\hline VIP1b & $<\mathrm{QL}$ & $<\mathrm{QL}$ & $0.063 \pm 0.010$ & $118 \pm 4$ & $733 \pm 10$ & $8.43 \pm 0.08$ & $137 \pm 1$ & $<\mathrm{QL}$ & $1.49 \pm 0.03$ & $3.03 \pm 0.05$ & $1.88 \pm 0.05$ & $0.052 \pm 0.004$ \\
\hline VIP1c & $<\mathrm{QL}$ & $<\mathrm{QL}$ & $0.068 \pm 0.018$ & $130 \pm 7$ & $732 \pm 5$ & $9.69 \pm 0.14$ & $138 \pm 1$ & $<\mathrm{QL}$ & $1.47 \pm 0.05$ & $3.00 \pm 0.09$ & $1.68 \pm 0.03$ & $0.051 \pm 0.001$ \\
\hline
\end{tabular}

keys to abbreviations: $\mathrm{Samp}=$ sample name

\subsection{Statistical Analysis Method}

The data was first recorded on excell and the statistical analysis is done for this purpose using SPSS (Statistical Package for Social Science), version 20.0 for the representation of boxplots.

\section{Results}

\subsection{Contamination Levels of Elements in Fruit Juices}

The data in Table 8 show Al in first place followed by $\mathrm{Sr}$, the concentrations of which are significantly higher than those of the other metals.

Table 8. Classification of contaminants according to the nature and origin of the juice

\begin{tabular}{|c|c|c|c|c|c|c|}
\hline Elements & FPJ & BPJ $100 \%$ & & PWC & SYR & Overall average \\
\hline \multicolumn{7}{|c|}{ Minor Elements (ppb) } \\
\hline $\mathrm{Al}$ & 1853,00 & 3999,29 & & 1600,67 & 162 & 3582,98 \\
\hline $\mathrm{Sr}$ & 860,00 & 953,59 & & 1088,11 & 317 & 953,76 \\
\hline $\mathrm{Ba}$ & 270,00 & 173,34 & & 332,28 & 233 & 195,87 \\
\hline \multicolumn{7}{|c|}{ Trace Elements (ppb) } \\
\hline $\mathrm{Pb}$ & 0,56 & 28,52 & & 6,69 & 1,36 & 24,26 \\
\hline Sn & 8,00 & 9,03 & & 8,79 & 10,3 & 8,74 \\
\hline $\mathrm{Tl}$ & 0,38 & 3,23 & & 2,06 & 0,21 & 2,88 \\
\hline As & 1,00 & 3,09 & & 1,53 & $<\mathrm{QL}$ & 2,72 \\
\hline Th & 2,33 & 2,17 & & 5,57 & 2,21 & 2,36 \\
\hline $\mathrm{Hg}$ & $<\mathrm{QL}$ & 1,7 & & $<\mathrm{QL}$ & $<\mathrm{QL}$ & 1,41 \\
\hline $\mathrm{Cd}$ & 1,00 & 0,13 & & 0,3 & 0,47 & 0,13 \\
\hline $\mathrm{Be}$ & $<\mathrm{QL}$ & 0,08 & & 0,18 & $<\mathrm{QL}$ & 0,09 \\
\hline $\mathrm{U}$ & 0,05 & 0,07 & & 0,07 & 0,05 & 0,07 \\
\hline \multicolumn{7}{|c|}{ Ultra trace Elements (ppb) } \\
\hline $\mathrm{Se}$ & $<\mathrm{QL}$ & $<\mathrm{QL}$ & $<\mathrm{QL}$ & $<\mathrm{QL}$ & $<\mathrm{QL}$ & $<\mathrm{QL}$ \\
\hline $\mathrm{Pt}$ & $<\mathrm{QL}$ & $<\mathrm{QL}$ & $<\mathrm{QL}$ & $<\mathrm{QL}$ & $<\mathrm{QL}$ & $<\mathrm{QL}$ \\
\hline $\mathrm{Ag}$ & $<\mathrm{QL}$ & $<\mathrm{QL}$ & $<\mathrm{QL}$ & $<\mathrm{QL}$ & $<\mathrm{QL}$ & $<\mathrm{QL}$ \\
\hline
\end{tabular}

keys to abbreviations: FPJ= French pineapple juice; BPJ= Beninese 100\% Pineapple juice; PWC $=$ Pineapple and Watermelon Cocktail from Benin; SYR= Syrup.

The statistical comparison of average concentrations based on the 92 samples analyzed shows groupings at 5 classification levels. The first group consisted of the element A1 who is of the order of ppm, the second group consisted of the element $\mathrm{Sr}$ of the order of one tenth of a ppm $(0.1 \mathrm{ppm})$, the third consisted of the element Ba intermediate between the second and fourth groups and the fourth group with the lead (of the order of ppb) at the upper end , and 
Uranium at the lower end. The fifth group of elements consisted of the triad (Ag, Pt and Se) has concentrations below the limit of quantification. These will not be taken into account for the analysis of the results, because the contents of these elements are below the various accepted standards in the matter. However, we will retain a classification at three levels of grouping, namely the microelements consisted of $\mathrm{Al}, \mathrm{Sr}$ and $\mathrm{Ba}$ which are of the order of ppm to some tens of $\mathrm{ppm}$, the trace elements consist of $\mathrm{Pb}, \mathrm{Sn}, \mathrm{Tl}, \mathrm{As}, \mathrm{Th}, \mathrm{Hg}, \mathrm{Cd}, \mathrm{Be}$ and $\mathrm{U}$ (which are of the order of ppb to a few tens of $\mathrm{ppb}$ ) and ultra trace elements consisted of $\mathrm{Se}, \mathrm{Ag}$ and $\mathrm{Pt}$ whose concentrations are below the limit of quantification. It should be noted that despite the high values of $\mathrm{Al}$ (first position) and $\mathrm{Sr}$ (second position), no reference standard for these two elements could be found either in relation to drinking water or by report to Codex Alimentarius (table 4).

The analysis of concentrations average shows only cases of non-compliance with respect to Hg compared to Benin standards and the WHO directive (1972) (see Table 4).

These results make it possible to classify the contaminants in the decreasing order of the concentrations in the following way: $\mathrm{Al}>\mathrm{Sr}>\mathrm{Ba}>\mathrm{Pb}>\mathrm{Sn}>\mathrm{Tl}>\mathrm{As}>\mathrm{Th}>\mathrm{Hg}>\mathrm{Cd}>\mathrm{Be}>\mathrm{U}$ (Table 8).

The classification according to contamination levels shows similar results regardless of the nature of the juice except for pineapple syrup which differs in size (table 8 ) and in the classification. It is as follows:

$-\mathrm{Al}>\mathrm{Sr}>\mathrm{Ba}>\mathrm{Pb}>\mathrm{Sn}>\mathrm{Tl}>\mathrm{As}>\mathrm{Th}>\mathrm{Hg}>\mathrm{Cd}>\mathrm{Be}>\mathrm{U}$ for the $100 \%$ pineapple juice produced in Benin (BPJ 100\%);

$-\mathrm{Al}>\mathrm{Sr}>\mathrm{Ba}>\mathrm{Sn}>\mathrm{Th}>\mathrm{Cd}>\mathrm{As}>\mathrm{Pb}>\mathrm{Tl}>\mathrm{U}$ for the 100\% pineapple juice produced in France (FPJ 00\%);

$-\mathrm{Al}>\mathrm{Sr}>\mathrm{Ba}>\mathrm{Sn}>\mathrm{Pb}>\mathrm{Th}>\mathrm{Tl}>\mathrm{As}>\mathrm{Cd}>\mathrm{Be}>\mathrm{U}$ for Pineapple and Watermelon Cocktail $(\mathrm{CPW})$ and

$-\mathrm{Sr}>\mathrm{Ba}>\mathrm{Al}>\mathrm{Sn}>\mathrm{Th}>\mathrm{Pb}>\mathrm{Cd}>\mathrm{Tl}>\mathrm{U}>\mathrm{As}>\mathrm{Be}>\mathrm{Hg}$ for pineapple syrup (SYR).

These results highlight the influence of the process in the intake of metallic contaminants in food, the syrup being less contaminated.

Overall, the three-class classification is valid regardless of the nature and origin of the fruit as well as the process of processing the fruit into juice. About $10 \%$ of Benin's juice samples contain traces of $\mathrm{Hg}$, representing four juice-producing units, this is due to possible accidental contamination.

\subsection{Comparative Analysis of Metallic Contaminant Levels Against Standards}

In order to assess the quality of the juices, we have taken for reference several national and international standards which are as follows: Beninese standards, Brazilian legislation, CODEX (1997), WHO (2006), Canadian legislation.

Thus, according to the results presented in Table 9 and Table 10, the maximum concentrations of chemical elements are below the norms except those of the $\mathrm{FRE}_{2}$ sample for $\mathrm{Ba}(1582 \mathrm{ppb})$ (Beninese and Canadian standards), of the sample $\left(\mathrm{JUA}_{6}\right)$ for $\mathrm{Hg}(31.7 \mathrm{ppb})$ Beninese and WHO standards (1972) and the OJA 4 sample for lead (608 ppb) (all reference standards used for water and Codex). Overall sample averages are below standard (Table 3) except for $\mathrm{Hg}$ (1.41 ppb). These three elements with high maxima will be further analyzed for contaminated samples as well as the production units affected by this contamination. According to the results in Table 9, the concentrations of $\mathrm{Ba}$ in $95 \%$ of samples comply with Beninese, Canadian and WHO legislation. For Al concentrations around 25\% of the samples analyzed comply with the WHO regulations, while more than $90 \%$ (percentile 0.90 ) of the analyzed samples have a concentration in $\mathrm{Hg}$ higher than the Beninese and $\mathrm{WHO}$ standards. For $\mathrm{Pb}, 95 \%$ of the samples comply with the Brazilian legislation, $90 \%$ with the Beninese standard and $50 \%$ with that of the WHO.

Table 9. Characteristics of dispersion of contaminant concentrations in juices (ppb)

\begin{tabular}{|c|c|c|c|c|c|c|c|c|c|}
\hline \multirow{2}{*}{ Elements } & \multirow{2}{*}{ Minimum } & \multirow{2}{*}{ Maximum } & \multirow{2}{*}{$S D$} & \multicolumn{6}{|c|}{ Percentiles } \\
\hline & & & & 0.25 & 0.50 & 0.75 & 0.90 & 0.95 & 0.99 \\
\hline As & $<\mathrm{QL}$ & 39.3 & 6.57 & 0.00 & 0.97 & 1.99 & 4.30 & 12.41 & 34.15 \\
\hline $\mathrm{Cd}$ & $<\mathrm{QL}$ & 0.7 & 0.22 & 0.00 & 0.00 & 0.35 & 0.48 & 0.57 & 0.68 \\
\hline $\mathrm{Be}$ & $<\mathrm{QL}$ & 0.59 & 0.1 & 0.00 & 0.08 & 0.12 & 0.18 & 0.21 & 0.50 \\
\hline $\mathrm{Al}$ & 26.4 & 30620 & 5979 & 219 & 848 & 4093 & 10367 & 15840 & 28563 \\
\hline $\mathrm{Sr}$ & 130 & 4049 & 494 & 704.50 & 819.50 & 1075 & 1395.60 & 1771.40 & 2421.52 \\
\hline Sn & $<\mathrm{QL}$ & 43 & 7.4 & 1.26 & 9.06 & 11.55 & 16.46 & 18.74 & 32.42 \\
\hline $\mathrm{Ba}$ & 42 & 1582 & 198 & 116.70 & 162 & 217 & 287.67 & 311.40 & 1278.40 \\
\hline $\mathrm{Hg}$ & $<\mathrm{QL}$ & 31.7 & 5.89 & 0.00 & 0.00 & 0.00 & 0.00 & 6.96 & 28.48 \\
\hline $\mathrm{Tl}$ & $<\mathrm{QL}$ & 21.3 & 4.01 & 0.72 & 1.41 & 2.88 & 7.06 & 11.22 & 19.55 \\
\hline $\mathrm{Pb}$ & $<\mathrm{QL}$ & 608 & 74.7 & 3.09 & 5.15 & 13.80 & 39.18 & 79.56 & 342.12 \\
\hline Th & $<\mathrm{QL}$ & 24.7 & 3.47 & 0.00 & 1.68 & 2.99 & 5.63 & 6.27 & 17.98 \\
\hline $\mathrm{U}$ & $<\mathrm{QL}$ & 1.04 & 0.14 & 0.02 & 0.04 & 0.06 & 0.09 & 0.22 & 0.63 \\
\hline
\end{tabular}

Here the concentrations lower than quantification limit (QL) are taken approximately equal to zero SD: Standard Deviation 
Table 10. Results of Metallic Contaminants Analyses

\begin{tabular}{|c|c|c|c|c|c|c|c|c|c|c|c|c|}
\hline \multirow[b]{2}{*}{ Samp } & \multirow[b]{2}{*}{ As } & \multirow[b]{2}{*}{$\mathrm{Cd}$} & \multirow[b]{2}{*}{$\mathrm{Be}$} & \multirow[b]{2}{*}{$\mathrm{Al}$} & \multirow[b]{2}{*}{$\mathrm{Sr}$} & \multirow[b]{2}{*}{ Sn } & \multirow[b]{2}{*}{$\mathrm{Ba}$} & Con & entrations in $\mathrm{e}$ & ments (in ppt & & \\
\hline & & & & & & & & $\mathrm{Hg}$ & $\mathrm{Tl}$ & $\mathrm{Pb}$ & $\mathrm{Th}$ & $\mathrm{U}$ \\
\hline ALA1 & $0.92 \pm 0.04$ & $0.42 \pm 0.04$ & $0.12 \pm 0.01$ & $82.7 \pm 4.1$ & $1200 \pm 10$ & $7.77 \pm 0.02$ & $213 \pm 1$ & $<\mathrm{QL}$ & $1.30 \pm 0.01$ & $3.71 \pm 0.03$ & $1.93 \pm 0.07$ & $0.032 \pm 0.006$ \\
\hline ALA2 & $<\mathrm{QL}$ & $0.38 \pm 0.09$ & $0.14 \pm 0.01$ & $65.2 \pm 4.0$ & $1158 \pm 12$ & $<\mathrm{QL}$ & $268 \pm 3$ & $<Q L$ & $2.61 \pm 0.03$ & $5.72 \pm 0.04$ & $1.65 \pm 0.07$ & $0.026 \pm 0.002$ \\
\hline ALO1 & $<\mathrm{QL}$ & $<\mathrm{QL}$ & $0.11 \pm 0.04$ & $111 \pm 6$ & $752 \pm 5$ & $11.4 \pm 0.23$ & $77.9 \pm 0.4$ & $<\mathrm{QL}$ & $1.34 \pm 0.01$ & $0.99 \pm 0.02$ & $2.85 \pm 0.13$ & $0.034 \pm 0.007$ \\
\hline ALO2 & $0.97 \pm 0.12$ & $0.55 \pm 0.04$ & $0.13 \pm 0.01$ & $39.7 \pm 1.5$ & $1035 \pm 14$ & $7.54 \pm 0.10$ & $222 \pm 2$ & $<\mathrm{QL}$ & $1.16 \pm 0.01$ & $2.07 \pm 0.03$ & $2.49 \pm 0.08$ & $0.031 \pm 0.001$ \\
\hline ALO3 & $2.42 \pm 0.12$ & $<\mathrm{QL}$ & $<\mathrm{QL}$ & $79.4 \pm 3.0$ & $1083 \pm 14$ & $<\mathrm{QL}$ & $229 \pm 2$ & $<\mathrm{QL}$ & $5.82 \pm 0.05$ & $2.80 \pm 0.02$ & $<\mathrm{QL}$ & $<\mathrm{QL}$ \\
\hline ALO4 & $<\mathrm{QL}$ & $0.38 \pm 0.07$ & $0.12 \pm 0.01$ & $39.8 \pm 2.0$ & $1041 \pm 14$ & $6.60 \pm 0.11$ & $223 \pm 1$ & $<\mathrm{QL}$ & $1.16 \pm 0.02$ & $2.49 \pm 0.07$ & $2.51 \pm 0.07$ & $0.032 \pm 0.005$ \\
\hline ALO5 & $1.67 \pm 0.32$ & $<\mathrm{QL}$ & $<\mathrm{QL}$ & $55.1 \pm 1.3$ & $788 \pm 12$ & $<\mathrm{QL}$ & $85.7 \pm 0.5$ & $<\mathrm{QL}$ & $6.52 \pm 0.21$ & $1.02 \pm 0.02$ & $<\mathrm{QL}$ & $<\mathrm{QL}$ \\
\hline ALO6 & $<\mathrm{QL}$ & $<\mathrm{QL}$ & $0.12 \pm 0.01$ & $26.4 \pm 1.2$ & $751 \pm 5$ & $6.00 \pm 0.08$ & $76.6 \pm 0.4$ & $<Q L$ & $1.30 \pm 0.02$ & $0.92 \pm 0.01$ & $2.49 \pm 0.10$ & $0.023 \pm 0.003$ \\
\hline BRA1 & $<\mathrm{QL}$ & $<\mathrm{QL}$ & $0.078 \pm 0.010$ & $389 \pm 18$ & $996 \pm 6$ & $9.70 \pm 0.13$ & $136 \pm 2$ & $<Q L$ & $1.21 \pm 0.03$ & $3.32 \pm 0.02$ & $1.50 \pm 0.03$ & $0.039 \pm 0.004$ \\
\hline BRA2 & $<\mathrm{QL}$ & $<\mathrm{QL}$ & $0.11 \pm 0.02$ & $424 \pm 21$ & $1019 \pm 9$ & $13.3 \pm 0.1$ & $140 \pm 1$ & $<\mathrm{QL}$ & $1.23 \pm 0.02$ & $4.22 \pm 0.13$ & $1.35 \pm 0.02$ & $0.036 \pm 0.003$ \\
\hline BRA3 & $0.93 \pm 0.10$ & $0.31 \pm 0.04$ & $0.11 \pm 0.04$ & $412 \pm 17$ & $1032 \pm 6$ & $13.7 \pm 0.1$ & $144 \pm 1$ & $<\mathrm{QL}$ & $1.21 \pm 0.02$ & $4.37 \pm 0.03$ & $1.22 \pm 0.03$ & $0.035 \pm 0.002$ \\
\hline BRA4 & $<\mathrm{QL}$ & $<\mathrm{QL}$ & $0.083 \pm 0.001$ & $425 \pm 14$ & $1021 \pm 7$ & $11.6 \pm 0.1$ & $138 \pm 1$ & $<\mathrm{QL}$ & $1.24 \pm 0.02$ & $3.43 \pm 0.04$ & $1.30 \pm 0.03$ & $0.034 \pm 0.005$ \\
\hline BRA5 & $<\mathrm{QL}$ & $0.36 \pm 0.05$ & $0.11 \pm 0.01$ & $416 \pm 21$ & $1034 \pm 5$ & $12.0 \pm 0.1$ & $143 \pm 1$ & $<\mathrm{QL}$ & $1.20 \pm 0.03$ & $4.55 \pm 0.02$ & $1.33 \pm 0.02$ & $0.037 \pm 0.005$ \\
\hline BRA6 & $<\mathrm{QL}$ & $<\mathrm{QL}$ & $0.067 \pm 0.016$ & $375 \pm 20$ & $1019 \pm 9$ & $7.68 \pm 0.08$ & $123 \pm 1$ & $<\mathrm{QL}$ & $1.38 \pm 0.03$ & $1.69 \pm 0.02$ & $1.21 \pm 0.05$ & $0.025 \pm 0.004$ \\
\hline CHA1 & $2.70 \pm 0.06$ & $<\mathrm{QL}$ & $<\mathrm{QL}$ & $3196 \pm 122$ & $1923 \pm 13$ & $<\mathrm{QL}$ & $291 \pm 3$ & $<\mathrm{QL}$ & $11.1 \pm 0.2$ & $8.41 \pm 0.03$ & $<\mathrm{QL}$ & $<\mathrm{QL}$ \\
\hline CHA2 & $3.25 \pm 0.20$ & $<\mathrm{QL}$ & $<\mathrm{QL}$ & $4620 \pm 144$ & $2001 \pm 16$ & $<\mathrm{QL}$ & $299 \pm 4$ & $<Q L$ & $11.4 \pm 0.1$ & $12.3 \pm 0.1$ & $<\mathrm{QL}$ & $<\mathrm{QL}$ \\
\hline CHA3 & $<\mathrm{QL}$ & $<\mathrm{QL}$ & $0.082 \pm 0.003$ & $2616 \pm 100$ & $1390 \pm 9$ & $14.2 \pm 0.13$ & $294 \pm 2$ & $<\mathrm{QL}$ & $2.16 \pm 0.02$ & $12.9 \pm 0.1$ & $2.12 \pm 0.05$ & $0.066 \pm 0.007$ \\
\hline CHA5 & $1.21 \pm 0.16$ & $<\mathrm{QL}$ & $<\mathrm{QL}$ & $2655 \pm 131$ & $545 \pm 6$ & $14.6 \pm 0.04$ & $71.0 \pm 0.6$ & $<\mathrm{QL}$ & $0.12 \pm 0.01$ & $8.53 \pm 0.03$ & $3.05 \pm 0.04$ & $0.038 \pm 0.003$ \\
\hline CHA6 & $3.50 \pm 0.26$ & $<\mathrm{QL}$ & $<\mathrm{QL}$ & $6213 \pm 28$ & $655 \pm 13$ & $<\mathrm{QL}$ & $96.5 \pm 1.2$ & $<\mathrm{QL}$ & $0.50 \pm 0.02$ & $12.8 \pm 0.1$ & $<\mathrm{QL}$ & $0.074 \pm 0.009$ \\
\hline FRU1 & $1.63 \pm 0.16$ & $<\mathrm{QL}$ & $<\mathrm{QL}$ & $6603 \pm 212$ & $786 \pm 5$ & $<\mathrm{QL}$ & $74.6 \pm 1.3$ & $<\mathrm{QL}$ & $2.69 \pm 0.04$ & $4.18 \pm 0.05$ & $<\mathrm{QL}$ & $<\mathrm{QL}$ \\
\hline FRU1 & $<\mathrm{QL}$ & $0.50 \pm 0.06$ & $0.092 \pm 0.011$ & $16455 \pm 869$ & $1146 \pm 7$ & $13.0 \pm 0.2$ & $187 \pm 2$ & $<\mathrm{QL}$ & $0.82 \pm 0.05$ & $9.94 \pm 0.07$ & $2.02 \pm 0.04$ & $0.056 \pm 0.005$ \\
\hline FRU2 & $1.55 \pm 0.33$ & $<\mathrm{QL}$ & $<\mathrm{QL}$ & $4152 \pm 88$ & $816 \pm 11$ & $<\mathrm{QL}$ & $77.7 \pm 0.9$ & $<\mathrm{QL}$ & $2.82 \pm 0.01$ & $4.91 \pm 0.11$ & $<\mathrm{QL}$ & $<\mathrm{QL}$ \\
\hline FRU2 & $<\mathrm{QL}$ & $0.42 \pm 0.04$ & $0.085 \pm 0.023$ & $16203 \pm 741$ & $1133 \pm 15$ & $11.9 \pm 0.1$ & $182 \pm 1$ & $<\mathrm{QL}$ & $0.79 \pm 0.01$ & $9.64 \pm 0.06$ & $2.05 \pm 0.01$ & $0.058 \pm 0.004$ \\
\hline FRU3 & $1.33 \pm 0.15$ & $<\mathrm{QL}$ & $<\mathrm{QL}$ & $4095 \pm 128$ & $816 \pm 5$ & $<\mathrm{QL}$ & $77.5 \pm 1.1$ & $<\mathrm{QL}$ & $2.90 \pm 0.06$ & $4.67 \pm 0.06$ & $<\mathrm{QL}$ & $<\mathrm{QL}$ \\
\hline FRU3 & $<\mathrm{QL}$ & $0.42 \pm 0.05$ & $0.088 \pm 0.016$ & $16701 \pm 665$ & $1137 \pm 15$ & $13.0 \pm 0.1$ & $184 \pm 1$ & $<\mathrm{QL}$ & $0.79 \pm 0.02$ & $10.0 \pm 0.1$ & $2.05 \pm 0.01$ & $0.055 \pm 0.006$ \\
\hline FRU4 & $1.37 \pm 0.20$ & $<\mathrm{QL}$ & $<\mathrm{QL}$ & $3942 \pm 46$ & $924 \pm 4$ & $<\mathrm{QL}$ & $170 \pm 1$ & $14.6 \pm 0.2$ & $7.48 \pm 0.10$ & $3.98 \pm 0.06$ & $<\mathrm{QL}$ & $<\mathrm{QL}$ \\
\hline FRU5 & $1.22 \pm 0.12$ & $<\mathrm{QL}$ & $<\mathrm{QL}$ & $4088 \pm 127$ & $926 \pm 7$ & $<Q L$ & $170 \pm 1$ & $25.4 \pm 0.2$ & $7.47 \pm 0.11$ & $3.97 \pm 0.02$ & $<\mathrm{QL}$ & $<\mathrm{QL}$ \\
\hline FRU6 & $1.29 \pm 0.03$ & $<\mathrm{QL}$ & $<\mathrm{QL}$ & $4004 \pm 75$ & $934 \pm 10$ & $<\mathrm{QL}$ & $170 \pm 1$ & $<\mathrm{QL}$ & $7.51 \pm 0.13$ & $4.21 \pm 0.10$ & $<\mathrm{QL}$ & $<\mathrm{QL}$ \\
\hline INN1 & $0.92 \pm 0.31$ & $0.42 \pm 0.02$ & $0.11 \pm 0.02$ & $135 \pm 6$ & $1257 \pm 10$ & $5.09 \pm 0.05$ & $292 \pm 2$ & $<\mathrm{QL}$ & $0.27 \pm 0.01$ & $0.29 \pm 0.01$ & $2.54 \pm 0.05$ & $0.027 \pm 0.002$ \\
\hline INN2 & $0.93 \pm 0.04$ & $<\mathrm{QL}$ & $0.12 \pm 0.02$ & $108 \pm 6$ & $1226 \pm 10$ & $<\mathrm{QL}$ & $283 \pm 4$ & $<\mathrm{QL}$ & $0.27 \pm 0.01$ & $0.44 \pm 0.01$ & $2.24 \pm 0.05$ & $0.031 \pm 0.002$ \\
\hline JAF2 & $0.91 \pm 0.16$ & $0.56 \pm 0.02$ & $0.080 \pm 0.007$ & $139 \pm 8$ & $790 \pm 12$ & $5.05 \pm 0.07$ & $267 \pm 1$ & $<\mathrm{QL}$ & $0.57 \pm 0.01$ & $0.27 \pm 0.01$ & $2.72 \pm 0.04$ & $0.060 \pm 0.002$ \\
\hline JUA2 & $3.46 \pm 0.32$ & $<\mathrm{QL}$ & $0.081 \pm 0.007$ & $1188 \pm 48$ & $600 \pm 2$ & $19.9 \pm 0.4$ & $184 \pm 2$ & $1.86 \pm 0.11$ & $3.83 \pm 0.02$ & $4.19 \pm 0.02$ & $4.24 \pm 0.18$ & $0.077 \pm 0.006$ \\
\hline JUA3 & $6.48 \pm 0.20$ & $<\mathrm{QL}$ & $<\mathrm{QL}$ & $472 \pm 17$ & $609 \pm 1$ & $<\mathrm{QL}$ & $189 \pm 2$ & $<\mathrm{QL}$ & $21.3 \pm 0.1$ & $5.05 \pm 0.07$ & $<\mathrm{QL}$ & $<\mathrm{QL}$ \\
\hline JUA4 & $1.97 \pm 0.18$ & $0.37 \pm 0.01$ & $0.10 \pm 0.03$ & $413 \pm 14$ & $617 \pm 8$ & $18.7 \pm 0.1$ & $203 \pm 1$ & $0.99 \pm 0.03$ & $4.37 \pm 0.04$ & $6.66 \pm 0.14$ & $1.61 \pm 0.03$ & $0.077 \pm 0.003$ \\
\hline JUA5 & $5.41 \pm 0.40$ & $<\mathrm{QL}$ & $<\mathrm{QL}$ & $143 \pm 6$ & $584 \pm 9$ & $<\mathrm{QL}$ & $176 \pm 1$ & $<\mathrm{QL}$ & $19.4 \pm 0.2$ & $2.37 \pm 0.03$ & $<\mathrm{QL}$ & $<\mathrm{QL}$ \\
\hline JUA6 & $4.85 \pm 0.08$ & $<\mathrm{QL}$ & $<\mathrm{QL}$ & $304 \pm 9$ & $678 \pm 9$ & $<\mathrm{QL}$ & $151 \pm 2$ & $31.7 \pm 0.6$ & $7.08 \pm 0.08$ & $3.03 \pm 0.02$ & $<\mathrm{QL}$ & $0.075 \pm 0.005$ \\
\hline JUD1 & $2.14 \pm 0.15$ & $0.45 \pm 0.10$ & $0.30 \pm 0.02$ & $2528 \pm 135$ & $735 \pm 3$ & $10.5 \pm 0.1$ & $159 \pm 1$ & $<\mathrm{QL}$ & $1.50 \pm 0.02$ & $11.4 \pm 0.1$ & $<\mathrm{QL}$ & $0.27 \pm 0.006$ \\
\hline JUD2 & $2.69 \pm 0.24$ & $<\mathrm{QL}$ & $0.49 \pm 0.02$ & $21488 \pm 925$ & $1765 \pm 5$ & $10.6 \pm 0.1$ & $173 \pm 2$ & $<\mathrm{QL}$ & $1.65 \pm 0.06$ & $15.3 \pm 0.6$ & $24.7 \pm 1.0$ & $0.54 \pm 0.01$ \\
\hline JUD3 & $2.89 \pm 0.46$ & $<\mathrm{QL}$ & $0.59 \pm 0.04$ & $30620 \pm 1145$ & $2280 \pm 18$ & $9.12 \pm 0.02$ & $181 \pm 1$ & $<\mathrm{QL}$ & $1.69 \pm 0.05$ & $16.8 \pm 0.2$ & $17.4 \pm 0.4$ & $0.59 \pm 0.01$ \\
\hline JUS1 & $<\mathrm{QL}$ & $0.48 \pm 0.07$ & $0.070 \pm 0.017$ & $8523 \pm 469$ & $903 \pm 9$ & $14.9 \pm 0.1$ & $168 \pm 1$ & $<\mathrm{QL}$ & $1.44 \pm 0.04$ & $31.4 \pm 0.1$ & $1.21 \pm 0.06$ & $0.039 \pm 0.002$ \\
\hline JUS2 & $2.04 \pm 0.18$ & $0.70 \pm 0.07$ & $0.086 \pm 0.004$ & $16109 \pm 871$ & $879 \pm 7$ & $31.5 \pm 0.4$ & $161 \pm 1$ & $<Q L$ & $1.44 \pm 0.01$ & $49.8 \pm 0.3$ & $<\mathrm{QL}$ & $0.091 \pm 0.009$ \\
\hline JUS3 & $1.99 \pm 0.03$ & $<\mathrm{QL}$ & $0.096 \pm 0.012$ & $8282 \pm 369$ & $912 \pm 5$ & $16.9 \pm 0.1$ & $163 \pm 1$ & $<\mathrm{QL}$ & $1.50 \pm 0.03$ & $31.1 \pm 0.4$ & $<\mathrm{QL}$ & $0.063 \pm 0.002$ \\
\hline JUV1 & $1.08 \pm 0.30$ & $<\mathrm{QL}$ & $0.10 \pm 0.01$ & $225 \pm 11$ & $985 \pm 15$ & $10.0 \pm 0.04$ & $143 \pm 2$ & $<\mathrm{QL}$ & $0.42 \pm 0.01$ & $24.8 \pm 0.2$ & $5.77 \pm 0.08$ & $0.043 \pm 0.004$ \\
\hline JUV2 & $1.02 \pm 0.15$ & $<\mathrm{QL}$ & $0.14 \pm 0.03$ & $788 \pm 41$ & $1052 \pm 7$ & $9.16 \pm 0.18$ & $146 \pm 1$ & $<\mathrm{QL}$ & $0.43 \pm 0.01$ & $25.1 \pm 0.1$ & $5.53 \pm 0.12$ & $0.051 \pm 0.008$ \\
\hline JUV3 & $<\mathrm{QL}$ & $<\mathrm{QL}$ & $0.10 \pm 0.01$ & $3558 \pm 146$ & $910 \pm 8$ & $12.9 \pm 0.12$ & $135 \pm 1$ & $<\mathrm{QL}$ & $0.41 \pm 0.03$ & $16.9 \pm 0.1$ & $7.32 \pm 0.24$ & $0.048 \pm 0.002$ \\
\hline JUV4 & $0.91 \pm 0.11$ & $<\mathrm{QL}$ & $0.19 \pm 0.03$ & $290 \pm 16$ & $516 \pm 7$ & $5.49 \pm 0.05$ & $89.9 \pm 0.6$ & $<\mathrm{QL}$ & $0.93 \pm 0.03$ & $7.06 \pm 0.08$ & $3.62 \pm 0.04$ & $0.057 \pm 0.005$ \\
\hline JUV5 & $0.96 \pm 0.09$ & $<\mathrm{QL}$ & $0.21 \pm 0.05$ & $349 \pm 12$ & $520 \pm 6$ & $6.31 \pm 0.07$ & $84.7 \pm 0.9$ & $<\mathrm{QL}$ & $0.96 \pm 0.01$ & $7.40 \pm 0.09$ & $3.73 \pm 0.08$ & $0.057 \pm 0.003$ \\
\hline JUV6 & $0.91 \pm 0.07$ & $<\mathrm{QL}$ & $0.21 \pm 0.05$ & $318 \pm 17$ & $518 \pm 4$ & $6.37 \pm 0.11$ & $84.8 \pm 0.7$ & $<\mathrm{QL}$ & $0.97 \pm 0.01$ & $7.09 \pm 0.13$ & $3.58 \pm 0.04$ & $0.057 \pm 0.001$ \\
\hline OJA2 & $18.3 \pm 0.6$ & $<\mathrm{QL}$ & $<\mathrm{QL}$ & $1167 \pm 21$ & $770 \pm 2$ & $17.3 \pm 0.1$ & $94.2 \pm 1.4$ & $<\mathrm{QL}$ & $4.06 \pm 0.06$ & $208 \pm 1$ & $<\mathrm{QL}$ & $<\mathrm{QL}$ \\
\hline OJA2 & $0.93 \pm 0.03$ & $<\mathrm{QL}$ & $0.063 \pm 0.008$ & $5074 \pm 250$ & $663 \pm 5$ & $18.3 \pm 0.3$ & $84.6 \pm 1.2$ & $<\mathrm{QL}$ & $0.14 \pm 0.01$ & $9.00 \pm 0.11$ & $2.67 \pm 0.04$ & $0.065 \pm 0.002$ \\
\hline OJA3 & $33.7 \pm 1.3$ & $<\mathrm{QL}$ & $<\mathrm{QL}$ & $1075 \pm 21$ & $1141 \pm 4$ & $18.6 \pm 0.3$ & $226 \pm 3$ & $26.0 \pm 0.4$ & $14.2 \pm 0.3$ & $319 \pm 1$ & $<\mathrm{QL}$ & $<\mathrm{QL}$ \\
\hline OJA3 & $<\mathrm{QL}$ & $<\mathrm{QL}$ & $0.056 \pm 0.011$ & $5158 \pm 230$ & $669 \pm 5$ & $16.9 \pm 0.2$ & $84.7 \pm 0.9$ & $<\mathrm{QL}$ & $0.14 \pm 0.01$ & $9.05 \pm 0.03$ & $2.53 \pm 0.06$ & $0.064 \pm 0.001$ \\
\hline OJA4 & $24.3 \pm 1.4$ & $<\mathrm{QL}$ & $<\mathrm{QL}$ & $8256 \pm 197$ & $1397 \pm 12$ & $43.0 \pm 0.7$ & $242 \pm 3$ & $<\mathrm{QL}$ & $16.8 \pm 0.2$ & $608 \pm 1$ & $<\mathrm{QL}$ & $<\mathrm{QL}$ \\
\hline OJA5 & $25.5 \pm 1.3$ & $<\mathrm{QL}$ & $<\mathrm{QL}$ & $3974 \pm 52$ & $811 \pm 9$ & $16.7 \pm 0.1$ & $60.6 \pm 0.7$ & $<\mathrm{QL}$ & $3.54 \pm 0.04$ & $59.9 \pm 0.6$ & $<\mathrm{QL}$ & $<\mathrm{QL}$ \\
\hline VIB2 & $<\mathrm{QL}$ & $0.47 \pm 0.06$ & $<\mathrm{QL}$ & $162 \pm 5$ & $317 \pm 3$ & $10.3 \pm 0.1$ & $233 \pm 3$ & $<\mathrm{QL}$ & $0.21 \pm 0.02$ & $1.36 \pm 0.03$ & $2.21 \pm 0.06$ & $0.047 \pm 0.004$ \\
\hline VIP2 & $2.16 \pm 0.02$ & $0.41 \pm 0.06$ & $<\mathrm{QL}$ & $150 \pm 6$ & $712 \pm 10$ & $18.8 \pm 0.6$ & $154 \pm 2$ & $0.62 \pm 0.02$ & $1.52 \pm 0.05$ & $3.89 \pm 0.13$ & $0.86 \pm 0.03$ & $0.061 \pm 0.003$ \\
\hline VIP3 & $8.49 \pm 0.44$ & $<\mathrm{QL}$ & $<\mathrm{QL}$ & $67.2 \pm 1.7$ & $326 \pm 2$ & $<\mathrm{QL}$ & $44.3 \pm 0.6$ & $<\mathrm{QL}$ & $<\mathrm{QL}$ & $1.02 \pm 0.03$ & $<\mathrm{QL}$ & $<\mathrm{QL}$ \\
\hline VIP4 & $1.76 \pm 0.13$ & $0.37 \pm 0.04$ & $0.084 \pm 0.003$ & $301 \pm 14$ & $654 \pm 10$ & $11.1 \pm 0.1$ & $108 \pm 1$ & $<\mathrm{QL}$ & $1.36 \pm 0.01$ & $3.54 \pm 0.02$ & $0.57 \pm 0.01$ & $0.087 \pm 0.007$ \\
\hline VIP5 & $3.90 \pm 0.15$ & $<\mathrm{QL}$ & $<\mathrm{QL}$ & $320 \pm 10$ & $720 \pm 7$ & $<\mathrm{QL}$ & $123 \pm 1$ & $28.2 \pm 1.0$ & $6.98 \pm 0.01$ & $3.73 \pm 0.02$ & $<\mathrm{QL}$ & $0.086 \pm 0.005$ \\
\hline VIP6 & $1.47 \pm 0.10$ & $0.36 \pm 0.01$ & $<\mathrm{QL}$ & $291 \pm 14$ & $654 \pm 3$ & $10.1 \pm 0.05$ & $108 \pm 1$ & $0.77 \pm 0.01$ & $1.36 \pm 0.01$ & $3.25 \pm 0.02$ & $1.04 \pm 0.03$ & $0.088 \pm 0.003$ \\
\hline VIP7 & $3.88 \pm 0.09$ & $<\mathrm{QL}$ & $<\mathrm{QL}$ & $363 \pm 11$ & $663 \pm 2$ & $<\mathrm{QL}$ & $119 \pm 1$ & $<\mathrm{QL}$ & $6.88 \pm 0.03$ & $3.67 \pm 0.12$ & $<\mathrm{QL}$ & $0.10 \pm 0.01$ \\
\hline VIT1 & $1.12 \pm 0.17$ & $<\mathrm{QL}$ & $0.12 \pm 0.02$ & $4717 \pm 146$ & $816 \pm 3$ & $30.0 \pm 0.3$ & $180 \pm 1$ & $<\mathrm{QL}$ & $1.12 \pm 0.03$ & $62.6 \pm 0.7$ & $5.65 \pm 0.09$ & $1.04 \pm 0.03$ \\
\hline VIT2 & $0.92 \pm 0.22$ & $<\mathrm{QL}$ & $0.11 \pm 0.02$ & $217 \pm 11$ & $814 \pm 9$ & $8.11 \pm 0.03$ & $145 \pm 1$ & $<\mathrm{QL}$ & $1.04 \pm 0.02$ & $32.3 \pm 0.2$ & $4.56 \pm 0.14$ & $0.032 \pm 0.004$ \\
\hline VIT3 & $<\mathrm{QL}$ & $<\mathrm{QL}$ & $0.095 \pm 0.012$ & $507 \pm 20$ & $777 \pm 6$ & $5.38 \pm 0.05$ & $145 \pm 1$ & $<\mathrm{QL}$ & $1.02 \pm 0.03$ & $19.8 \pm 0.2$ & $3.59 \pm 0.07$ & $0.033 \pm 0.003$ \\
\hline VIT4 & $<\mathrm{QL}$ & $<\mathrm{QL}$ & $0.11 \pm 0.01$ & $497 \pm 25$ & $1167 \pm 3$ & $10.3 \pm 0.1$ & $155 \pm 2$ & $<\mathrm{QL}$ & $0.57 \pm 0.03$ & $40.9 \pm 0.5$ & $5.04 \pm 0.29$ & $0.052 \pm 0.005$ \\
\hline VIT5 & $1.06 \pm 0.25$ & $<\mathrm{QL}$ & $0.12 \pm 0.01$ & $1018 \pm 54$ & $1198 \pm 9$ & $9.88 \pm 0.11$ & $157 \pm 1$ & $<\mathrm{QL}$ & $0.53 \pm 0.01$ & $115 \pm 1$ & $4.06 \pm 0.04$ & $0.032 \pm 0.003$ \\
\hline VIT6 & $<\mathrm{QL}$ & $<\mathrm{QL}$ & $0.096 \pm 0.009$ & $493 \pm 19$ & $1177 \pm 13$ & $10.1 \pm 0.1$ & $158 \pm 1$ & $<\mathrm{QL}$ & $0.57 \pm 0.01$ & $41.1 \pm 0.2$ & $3.64 \pm 0.06$ & $0.056 \pm 0.008$ \\
\hline
\end{tabular}

keys to abbreviations: Samp: Samples

The purpose of the analysis of dispersion characteristics around the median (percentiles) and the average is to highlight the proportion of samples affected by the contamination of juices (Table 9). 
Thus, more than $75 \%$ of the samples have a concentration lower than the average in $\mathrm{As}, \mathrm{Hg}$ and $\mathrm{Pb}$ elements. On the other hand, for $\mathrm{As}, \mathrm{Tl}$ and $\mathrm{U}$, more than $75 \%$ of the values are lower than or equal to the average, whereas the elements $\mathrm{Cd}, \mathrm{Be}, \mathrm{Al}, \mathrm{Sr}, \mathrm{Sn}, \mathrm{Ba}$, Th have more than $75 \%$ above average values $\left(\mathrm{Q}_{3}\right)$. Nevertheless, $\mathrm{Be}, \mathrm{Sn}$ and $\mathrm{Ba}$ in a lesser measure are uniformly distributed around the mean (average close to the median). The calculated averages of the samples comply with the different standards except $\mathrm{Hg}$, of which more than $75 \%\left(\mathrm{Q}_{1}\right)$ of the samples comply with international standards (Table 4). Box-and-mustache graphs will further identify certain manufacturing units that do not meet the standards for $\mathrm{Ba}, \mathrm{Hg}$ and $\mathrm{Pb}$.

The analysis of average concentrations (Table 4) shows only cases of non-compliance with respect to Hg compared to Benin standards and the WHO directive (1972). These are FRU (6.67 ppb), JUA (5.76 ppb), OJA (5.20 ppb) and VIP (4.14 ppb). Further analysis by sample will allow us to highlight any major contaminations to the elements studied.

\subsection{Comparative Analysis of Pineapple Juices and Syrup Versus Microelements (or Minor Elements)}

Although Al, Sr and Ba were at the higher end of the classification in increasing order of element concentrations, only $\mathrm{Sr}$ is not regulated on human drinking water. The representation of the concentrations of the samples according to the unit highlights the contributions of the different units in the distribution with respect to the mean and median.

A comparative analysis of the four types of beverage compared to the minor elements shows that $100 \%$ pineapple juice has the highest levels of Al while the cocktail has similar levels of Sr to those of French juice (Table 8). On the other hand, the contents of $\mathrm{Sr}$ are similar in the juices. The distribution of $\mathrm{Ba}$ is on average the same as the process.

Compared to the minor elements and the same juice manufacturer, the comparison of $100 \%$ juice of pineapple with the cocktail reveals on the whole a higher rate of $\mathrm{Al}$ and $\mathrm{Sr}$ (Table 8).

\subsection{Comparative Analysis of Pineapple Juices and Syrup Versus Trace Elements}

As for trace elements, $\mathrm{Pb}$ is predominant in Benin juices and much larger in $100 \%$ pineapple juice than in other products (Table 8). On the other hand, Sn contents are uniform in all products. In addition, there is a slight increase in the $\mathrm{Cd}$ concentration in cocktails compared to other products.

Apart from Sn, which is uniform in all juices, the syrup is generally less contaminated with toxic metals. Lead $(\mathrm{Pb})$ concentration levels are determined by the contaminated soil because pineapple plantations are generally located near roads. The tin (Sn) appears in $100 \%$ pineapple juice samples and is not found at all in cocktails. The cocktail proved to be more contaminated by $\mathrm{Tl}$ than $100 \%$ pineapple but the $\mathrm{Pb}$ is in similar rates in the juice as in the cocktail. Watermelon is believed to be the main source of $\mathrm{Tl}$, while other trace elements, especially $\mathrm{Sn}$, are thought to be tributaries of pineapple.

\subsection{Contamination by Microelements in Some Units}

\subsubsection{Intra-Unit Variability of Microelements}

Although $\mathrm{Al}, \mathrm{Sr}$ and $\mathrm{Ba}$ are at the higher end of the classification in increasing order of element concentrations, only Ba is regulated on human drinking water. The representation of the concentrations of the samples according to the unit highlights the contributions of the different units in the distribution with respect to the average and the median (Figure 2). JUD, SAN units more particularly; JUS and JAF are the most determinant in this distribution for Aluminum (Table 11). On the other hand FRE, JUD and SAN for the Sr and finally FRE and SAN for the Ba are the most determinants for the strong values obtained. However, there is no standard for classifying the $\mathrm{Al}$ and $\mathrm{Sr}$ elements despite their preponderance (Table 10). For Ba, FRE juices show above-standard concentrations of 1000 ppb while $\mathrm{FRE}_{2}$ and $\mathrm{FRE}_{4}$ have concentrations of $1582 \mathrm{ppb}$ and $1252 \mathrm{ppb}$ respectively (Table 10). These values are higher than those obtained in the literature review (tables $1 \& 2$ ). 
Table 11. Average concentrations according to chemical elements and juice production units

\begin{tabular}{|c|c|c|c|c|c|c|c|c|c|c|c|c|c|}
\hline \multirow[b]{2}{*}{ Unit } & \multirow[b]{2}{*}{$\mathrm{N}$} & \multicolumn{12}{|c|}{ Element concentrations (in ppb) } \\
\hline & & As & $\mathrm{Cd}$ & $\mathrm{Be}$ & $\mathrm{Al}$ & $\mathrm{Sr}$ & $\mathrm{Sn}$ & $\mathrm{Ba}$ & $\mathrm{Hg}$ & $\mathrm{Tl}$ & $\mathrm{Pb}$ & Th & $\mathrm{U}$ \\
\hline ALA & 2 & 0.46 & 0.40 & 0.13 & 73.95 & 1179 & 3.88 & 240.50 & $<\mathrm{QL}$ & 1.96 & 4.71 & 1.79 & 0.03 \\
\hline ALO & 6 & 0.84 & 0.16 & 0.08 & 58.60 & 908 & 5.26 & 152.40 & $<\mathrm{QL}$ & 2.88 & 1.72 & 1.72 & 0.02 \\
\hline BRA & 6 & 0.16 & 0.11 & 0.09 & 407 & 1020 & 11.33 & 137.33 & $<\mathrm{QL}$ & 1.25 & 3.60 & 1.32 & 0.03 \\
\hline CHA & 6 & 2.51 & $<Q L$ & 0.01 & 3509 & 1107 & 4.80 & 182.30 & $<\mathrm{QL}$ & 4.21 & 9.34 & 0.86 & 0.06 \\
\hline FRE & 5 & 0.60 & 0.06 & 0.02 & 3288 & 1289 & 3.79 & 633 & $<\mathrm{QL}$ & 3.14 & 4.22 & 0.34 & 0.07 \\
\hline FRU & 6 & 1.40 & $<\mathrm{QL}$ & $<\mathrm{QL}$ & 4481 & 867 & 0.00 & 123.30 & 6.67 & 5.14 & 4.32 & $<Q L$ & $<\mathrm{QL}$ \\
\hline INN & 2 & 0.92 & 0.49 & 0.10 & 137 & 1024 & 5.07 & 279.50 & $<\mathrm{QL}$ & 0.42 & 0.28 & 2.63 & 0.04 \\
\hline JAF & 2 & 0.82 & 0.30 & 0.10 & 5290 & 789 & 8.44 & 253.30 & $<\mathrm{QL}$ & 0.30 & 0.17 & 1.09 & 0.03 \\
\hline JUA & 6 & 3.70 & 0.06 & 0.03 & 571 & 623 & 8.09 & 186.83 & 5.76 & 9.52 & 4.16 & 1.27 & 0.04 \\
\hline JUD & 3 & 2.57 & 0.15 & 0.46 & 18212 & 1593 & 10.07 & 171 & $<\mathrm{QL}$ & 1.61 & 14.50 & 14.03 & 0.47 \\
\hline JUS & 3 & 1.34 & 0.39 & 0.08 & 10971 & 898 & 21.10 & 164 & $<\mathrm{QL}$ & 1.46 & 37.43 & 0.40 & 0.06 \\
\hline JUV & 6 & 0.81 & $<Q L$ & 0.16 & 921 & 750 & 8.37 & 114 & $<\mathrm{QL}$ & 0.69 & 14.73 & 4.93 & 0.05 \\
\hline LAS & 1 & $<Q L$ & $<\mathrm{QL}$ & 0.08 & 30199 & 1112 & 6.73 & 119 & $<\mathrm{QL}$ & 1.51 & 22.70 & 1.53 & 0.07 \\
\hline OJA & 5 & 28.22 & $<\mathrm{QL}$ & $<\mathrm{QL}$ & 3121 & 969 & 22.14 & 1423 & 5.20 & 8.62 & 260 & $<\mathrm{QL}$ & $<\mathrm{QL}$ \\
\hline PAS & 6 & 1.29 & $<\mathrm{QL}$ & 0.19 & 179.30 & 784 & 8.56 & 199 & $<\mathrm{QL}$ & 2.05 & 7.80 & 6.21 & 0.04 \\
\hline SAN & 9 & 0.22 & 0.46 & 0.12 & 13714 & 1268 & 12.06 & 240 & $<\mathrm{QL}$ & 1.08 & 6.89 & 2.25 & 0.06 \\
\hline SIR & 1 & $<\mathrm{QL}$ & 0.47 & $<\mathrm{QL}$ & 162 & 317 & 10.30 & 233 & $<\mathrm{QL}$ & 0.21 & 1.36 & 2.21 & 0.05 \\
\hline TRO & 2 & $<\mathrm{QL}$ & 0.16 & 0.09 & 1182 & 918 & 9.16 & 115 & $<\mathrm{QL}$ & 0.66 & 24.95 & 1.40 & 0.03 \\
\hline VIB & 2 & 0.47 & 0.22 & 0.08 & 133.30 & 769 & 5.30 & 279 & $<\mathrm{QL}$ & 0.23 & 0.95 & 2.10 & 0.04 \\
\hline VIP & 7 & 2.79 & 0.10 & 0.03 & 228 & 640 & 5.61 & 111 & 4.14 & 2.79 & 3.03 & 0.80 & 0.07 \\
\hline
\end{tabular}

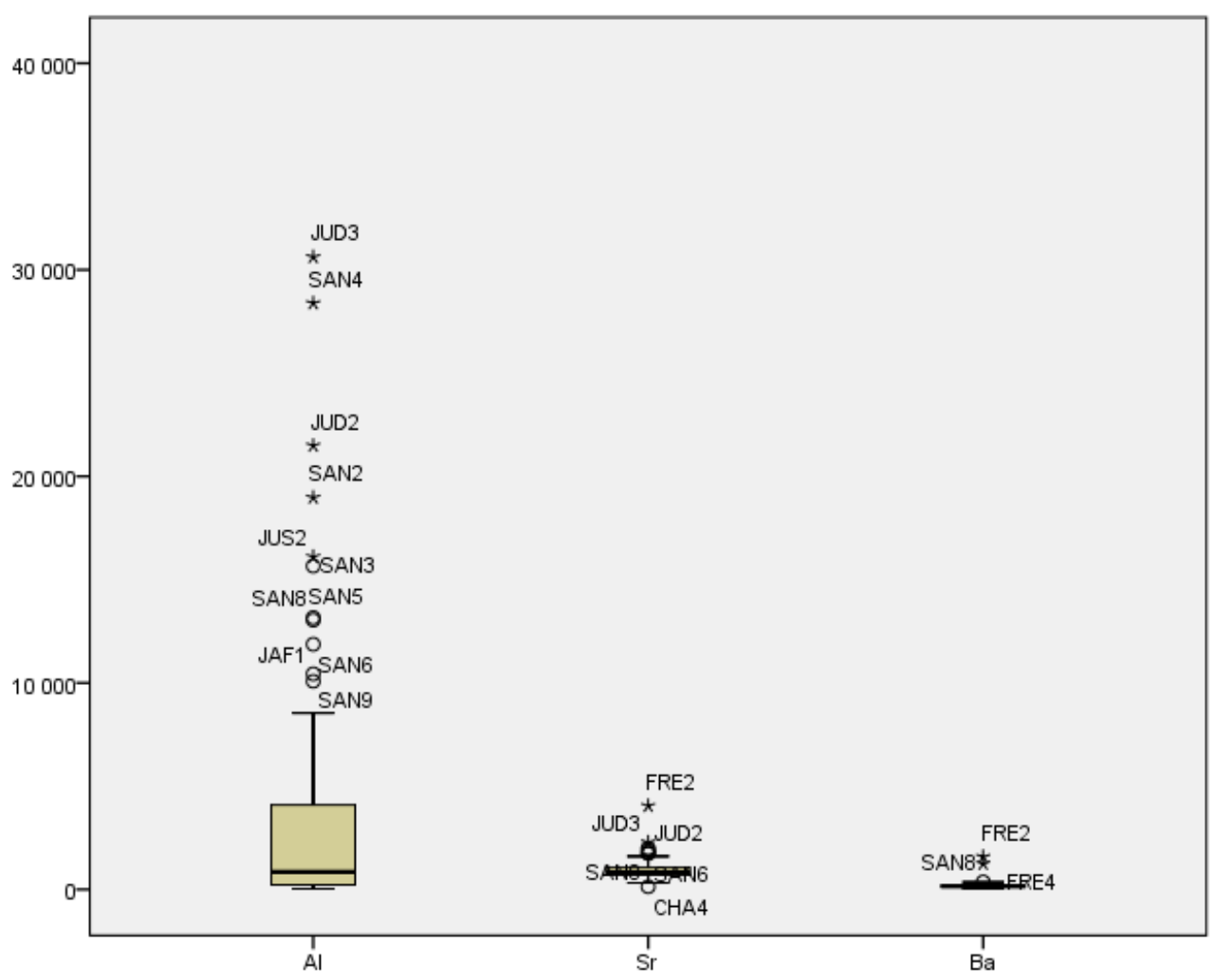

Figure 2. Whisker box distribution diagram for $\mathrm{Al}, \mathrm{Sr}$ and $\mathrm{Ba}$ concentrations in $\mathrm{ppb}$

3.5.2 Intra-Unit Variability of Trace Element Concentrations $(\mathrm{Hg}$ and $\mathrm{Pb})$

\section{Case of mercury $(\mathbf{H g})$}

Of all the trace elements, only Hg and lead have sufficiently high levels that can exceed the standard (Figures 3 and 4) as indicated in the previous paragraph.

As for $\mathrm{Hg}$, the units FRU, JUA, OJA and VIP presented values higher than the different existing standards which fix a concentration limit of $1 \mathrm{ppb}$ (Table 4), if the $\mathrm{JUA}_{4}$ unit has a concentration at the limit of the standards $(0.99 \mathrm{ppb})$, the concentrations of $\mathrm{JUA}_{2}$ and more particularly of $\mathrm{JUA}_{6}$ are above the norms with values of $1.86 \mathrm{ppb}$ and $31.70 \mathrm{ppb}$ respectively; the same is true of $\mathrm{OJA}_{3}$ and $\mathrm{VIP}_{3}$ with concentrations of $26.00 \mathrm{ppb}$ and $28.20 \mathrm{ppb}$ respectively. The FRU 
unit is also concerned by the contamination with $\mathrm{Hg}$, in particular with $\mathrm{FRU}_{4}$ and FRU5 the $\mathrm{Hg}$ concentrations of which are respectively $14.6 \mathrm{ppm}$ and $25.40 \mathrm{ppm}$. These values are higher than that in literature literature review (Tables $1 \& 2$ ).

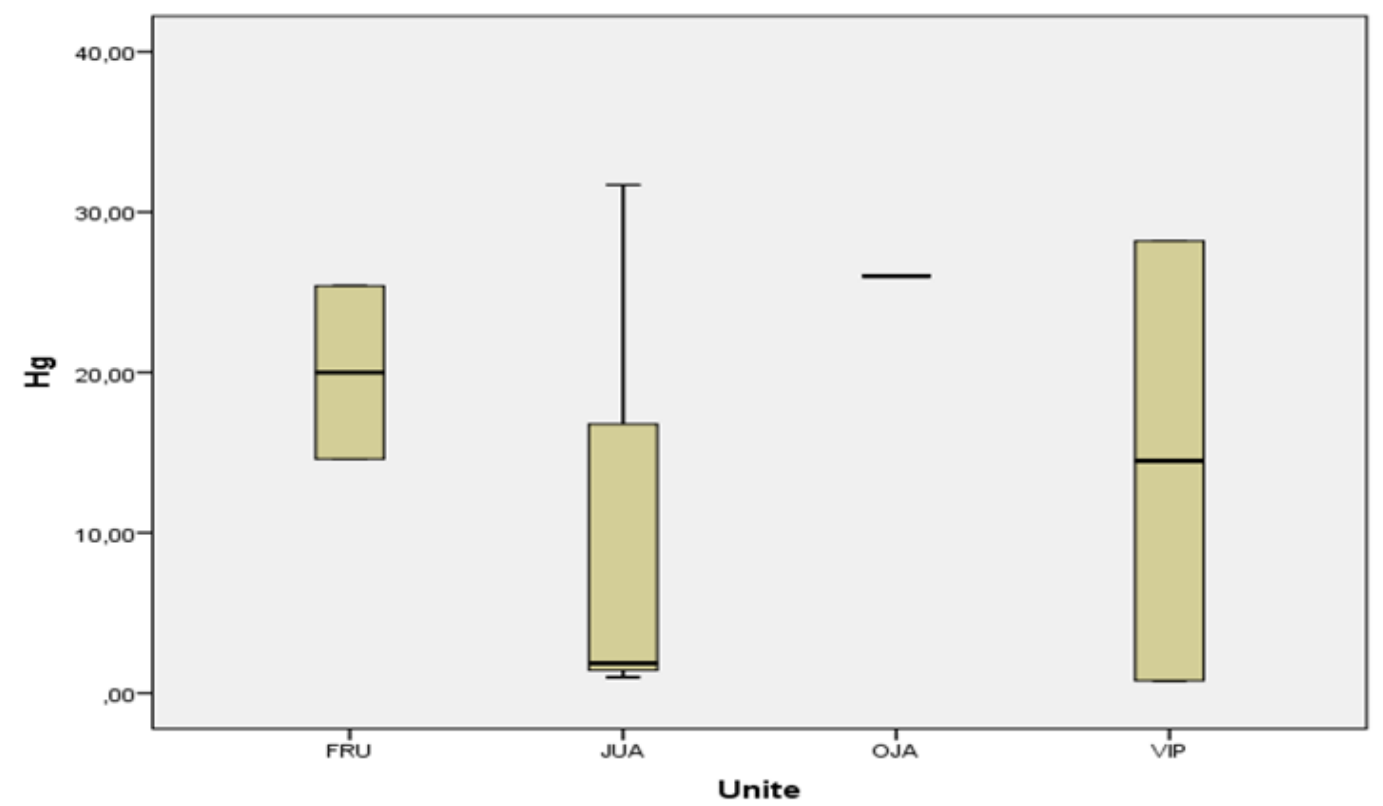

Figure 3. Whisker boxdistribution diagram for $\mathrm{Hg}$ concentrations in $\mathrm{ppb}$ according to the production units

\section{Case of lead $(\mathrm{Pb})$}

With regard to $\mathrm{Pb}$, the units OJA, VIT, JUS and TRO are shown by the graph of Figure 4. They have concentrations exceeding the standards which are $50 \mathrm{ppb}$.

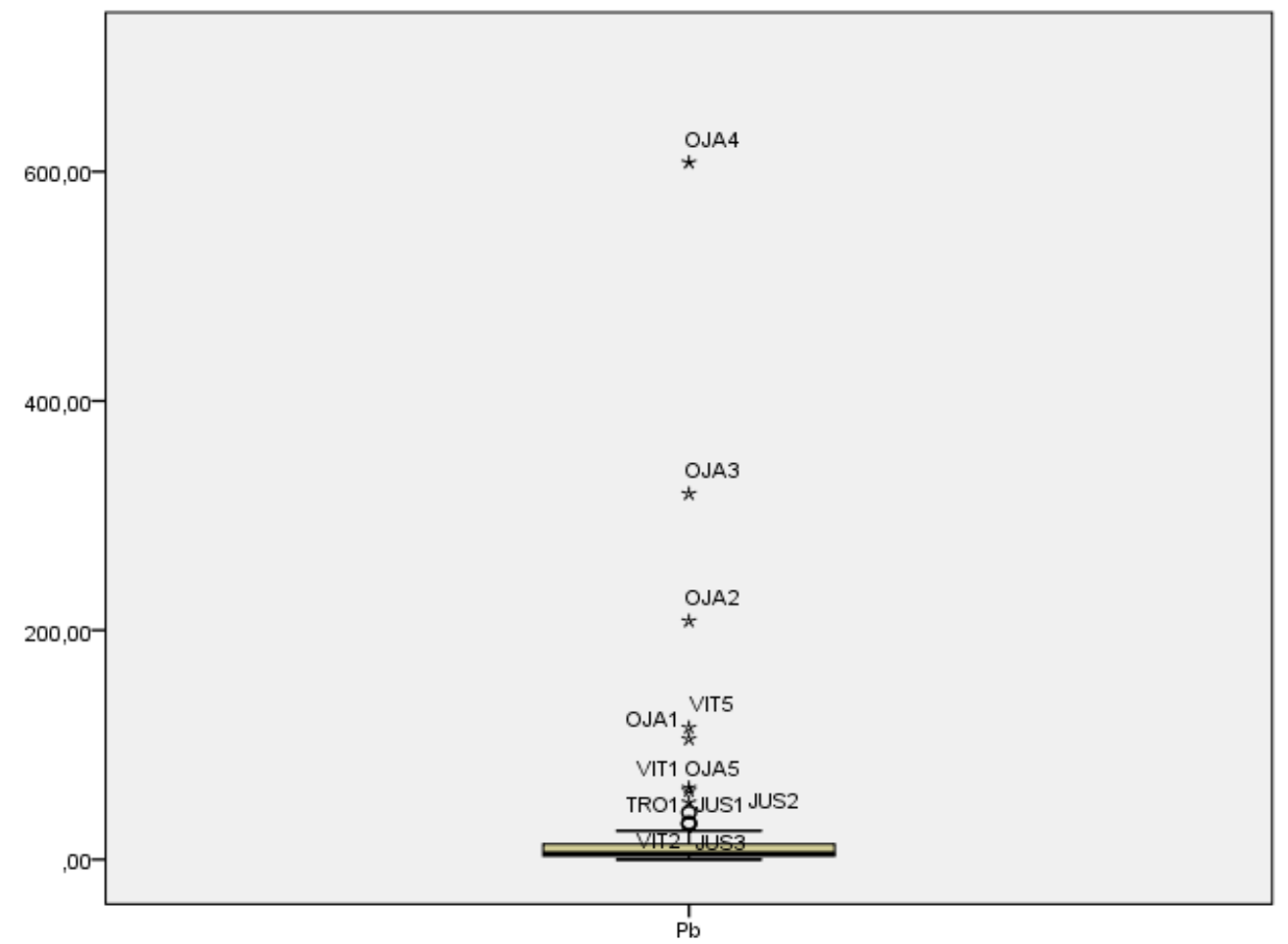

Figure 4. Whisker box distribution diagram for $\mathrm{Pb}$ concentrations in $\mathrm{ppb}$

All juices from OJA unit production contain more than twice the reference value of Benin (Table 11) and Codex (50 ppb) but JUS approaches with a concentration of $49.80 \mathrm{ppm}$ for $\mathrm{JUS}_{2}$ (Table 10). The VIT1 juice sample from the VIT unit also crossed the threshold with a concentration of $62.60 \mathrm{ppb}$. These values are slightly above the results of the literature. 
Finding substantial amounts of contaminants in the various juice samples cited above raises the issue of food control. These studies should be appraised in order to determine precisely the source of contamination and to consider source elimination strategies for bringing products up to standard.

\section{Discussion}

According to Anna Szymczycha-Madeja and al. (2013), the concentrations of $\mathrm{Al}, \mathrm{Cd}, \mathrm{Pb}$ determined in pineapple juices by ICP-MS are below the limit of quantification, except for Ba for which they obtained $38 \mathrm{ppb}$, while reviews of the literature on pineapple juices (Adetola and al. 199; Szymczycha-Madeja and al. 2014) revealed concentrations in the following ranges (in ppb): Al (ND-4200 ppb) (Braganca et al. 2011; Szymczycha-Madeja and al. 2013; Arruda and al. 1993; Bao and al. 1999; Lopez and al. 2002; Santos Froes and al. 2009), Ba (40-110 ppb) (Szymczycha-Madeja and al. 2013; Santos Froes and al. 2009), Cd (ND-12 ppb) (Tormen and al. 2011; Szymczycha-Madeja and al. 2013; Williams and al. 2010; Santos Froes and al. 2009), Pb (ND-240 ppb) (Tormen and al. 2011; Szymczycha-Madeja and al. 2013; Santos Froes and al. 2009), Se (14-15 ppb) (Arruda and al. 1994), Sn (ND-450 ppb) (Hotegni and al. 2016; Szymczycha-Madejaand al. 2014) and Sr (88-620 ppb) (2; Williams and al. 2010; Camara and al. 1995). These values are lower than the extreme values obtained during this work for $\mathrm{Al}, \mathrm{Ba}, \mathrm{Pb}$ and $\mathrm{Sr}$ (Table 2). On the other hand, these concentrations are higher for $\mathrm{Cd}$, Se and $\mathrm{Sn}$ than those presented in this study.

In addition, Lai and al. (2016) have obtained the following concentrations: $\mathrm{Al}$ (88 ppb), Ba (114 ppb), Cd (12 ppb), Pb $(236 \mathrm{ppb})$, and $\mathrm{Sr}(621 \mathrm{ppb})$. These concentrations are lower than those obtained during the present study except for the lower $\mathrm{Pb}$ and the $\mathrm{Cd}$, which is consistent with our results (Table 2).

Paula and al. (2015) have made a rapid assessment of the metallic contamination in commercial fruit juices by inductively coupled mass spectrometry after simple dilution. The mean values obtained for pineapple juice are $880 \mathrm{ppb}$ for $\mathrm{Sr}, 1.1 \mathrm{ppb}$ for $\mathrm{Cd}$ and $1.6 \mathrm{ppb}$ for $\mathrm{Pb}$. If the mean values obtained in our work are consistent with these results for $\mathrm{Sr}$, this is not the case for the mean $\mathrm{Cd}$ concentrations which is higher and $\mathrm{Pb}$ which is lower than our results (Table 3). But the average grades of $\mathrm{Pb}$ are similar to those of (Paula and al. 2015) and al. who obtained (20.75 $\mu \mathrm{g} / \mathrm{l})$ for $\mathrm{Pb}$ concentration (Table 1 and 2).

Pineapple is the main source of $\mathrm{Al}$ and $\mathrm{Sr}$ in juices. Ba would be provided by ferralitic soils characteristic of the study area (Figure 3). These results are in agreement with those of (Paula and al. 2015) who established that pre- and post-harvest factors determine the levels of the selected risk elements in $100 \%$ fruit juices.

However, there is no standard for classifying the $\mathrm{Al}$ and $\mathrm{Sr}$ elements despite their preponderance (Figure 2). Some values of $\mathrm{Ba}$ (three samples) are higher than those obtained in the literature (Codex Alimentarius 1999; Miele and al. 2014; Szymczycha-Madeja and al. 2014; Szymczycha-Madeja and al. 2013).

Overall, the syrup contains fewer pollutants than the entire juices combined. Would it be a average of eliminating these elements? If this is the case, a deepening of the phenomenon would make it possible to find a definitive solution to the decontamination of juices.

Finding substantial amounts of contaminants in the various juice samples cited above raises the issue of food control. These studies should be appraised in order to determine precisely the source of contamination and to consider source elimination strategies for bringing products up to standard.

\section{Conclusion}

The concentration averages are consistent with that of the literature. These averages show juices, for the most part, in compliance with quality standards of food and drinking water. However, some juice samples are heavily contaminated, especially in $\mathrm{Pb}, \mathrm{Hg}$ and $\mathrm{Ba}$, which sometimes exceeds the reference standards. $\mathrm{Al}$ and $\mathrm{Sr}$ showed the highest levels of contamination, although $\mathrm{Sr}$ is not regulated by individual countries and World Health Organization (WHO). This study opens perspectives of deepening allowing to understand the mechanism of migration of the contaminants in the human food chain and to propose strategies of bringing back to norm of the products manufactured in the units concerned by the high levels of contaminants.

\section{Acknowledgments}

This article was not supported by any grant or funding. The authors wish to thank the anonymous reviewers for their contributions to the manuscript. The authors are also grateful to:

- Jean Andino, Civil and Environmental Engineering FAMU/FSU College of Engineering, USA.

- Andrew A. Erakhrumen, PhD/ Department of Forest Resources and Wildlife Management/Faculty of Agriculture, University of Benin, Benin City, Nigeria. 


\section{References}

Arruda, M. A. Z., Gallego, M., \& Valcarcel, M. (1993). Determination of aluminum in slurry and liquid phase of juices by flow injection analysis graphite furnace atomic absorption spectrometry, Analytical Chemistry, 65, 3331-3335. https://doi.org/10.1021/ac00070a027

Arruda, M. A. Z., Gallego, M., \& Valcarcel, M. (1994) Determination of selenium in fruit juices by flow injection electrothermal atomization atomic absorption spectrometry, Journal of Analytical Atomic Spectrometry, May 1994, 9, 657-662.

Bao, S. X., Wan, Z. H., \& Liu J. S. (1999). X-ray fluorescence of trace elements in fruit juice, Spectrochimica Acta Part B 54, 1893-1897. https://doi.org/10.1016/S0584-8547(99)00160-3

Beattie, J., Nguyen, K., \& Quoc, T. (2000). Manganese in pineapple juices, Food Chemistry, 68, 37-39. https://doi.org/10.1016/S0308-8146(99)00149-1

Braganca, C. V. L., Meinikov, P., \& Zanoni, L. Z. (2012). Trace elements in fruit juices, Biological Trace Element Research, 146, 256-261. https://doi.org/10.1007/s12011-011-9247-y

Camara M., Diez, C., \& Torija, E. (1995). Chemical characterization of pineapple juices and nectars. Principal component analysis, Food Chemistry, 54, 93-100. https://doi.org/10.1016/0308-8146(95)92668-A

Codex Alimentarius. (1997). Codex general standard for contaminants and toxins in foods (Codex Stan 193-1995, rev.1-1997).

Hotegni, V. N. F. , Lommen, W. J. M., Van der Vorst, J. G. A. J., Agbossou, E. K., \& Struik, P. C. (2012). Analysis of Pineapple Production Systems in Benin, Eds.: J.-N. Wünsche and L.G. Albrigo, Acta Hort. 928, ISHS pp. 47 - 58. https://doi.org/10.1007/s12161-015-0136-4

Hotegni, V. N. F., Lommen, W. J. M., Agbossou, E. K., \& Struik, P. C. (2015). Influence of weight and type of planting material on fruit quality and its heterogeneity in pineapple Ananas comosus (L.), Frontiers in Plante Science, 5 , 1-16. https://doi.org/10.3389/fpls.2014.00798

Hotegni, V. N. F., Lommen, W. J. M., Agbossou, E. K., \& Struik, P. C. (2016). Understanding the effects of slip pruning on pineapple fruit quality, Acta Horticulturae 1111, ISHS. Eds.: J.-N. Wünsche and L.G. Albrigo Acta Hort. 928 , ISHS 2012, 231-240. https://doi.org/10.17660/ActaHortic.2016.1111.34

Hotegni, V. N. F., Lommen, W. J. M., van der Vorst, J. G. A., Agbossou, E. K., \& Struik, P. C. (2014). Bottlenecks and Opportunities for Quality Improvement in Fresh Pineapple Supply Chains in Benin, International Food and Agribusiness Management Review, 17(3), 139-170.

Kiliç, S., Yenisoy-Karakas, \& Kiliç, M. (2015). Metal contamination in fruit juices in Turkey: method validation and uncertainty budget; Food Analytical Methods, 8(10), 2487-2495. https://doi.org/10.1007/s12161-015-0136-4

Krejpcio, Z., Sionkowski, S., \& Bartela, J. (2005). Safety of fresh fruits and juices available on the Polish market as determined by heavy metal residues, Polish Journal of Environmental Studies, 14(6), 877-881.

Lai, G., Chen, G., \& Chen, T. (2016). Speciation of AsIII and AsV in fruit juices by dispersive liquid-liquid microextraction and hydride generation-atomic fluorescence spectrometry Speciation of AsIII and AsV in fruit juices by dispersive liquid-liquid microextraction and hydride generation-atomic fluorescence spectrometry, Food Chemistry, 190, 158-163. https://doi.org/10.1016/j.foodchem.2015.05.052

Liu, Y., Gong, B., Li Z., Xu, Y., \& Lin, T. (1999). Direct determination of selenium in a wild fruit juice by electrothermal atomic absorption spectrometry, 43(7), 985-989. https://doi.org/10.1016/0039-9140(95)01800-X

Lopez, F. F., Cabrera, C., Lorenzo, M. L., \& Lopez, M. C. (2002). Aluminum content of drinking waters, fruit juices and soft drinks: contribution to dietary intake, Science of The Total Environment, 292(3), 26 June 2002, $205-213$. https://doi.org/10.1016/S0048-9697(01)01122-6

Miele, A, Rizzdn, L. A., do Nascimento, de Queirdz, S. C., \& Gianelld, C. (2014). Physico-chemical composition, minerals, and pesticide residues in organic grape juices organic grape juices. Food Science and Technology, http://dx.doi.org/10.1590/1678-454457X.6540. ISSN 0101-2061

Oliveira, A. P., Neto, J. A. G., Nobrega, J. A., Correia, P. R. M., \& Oliveira, P. V. (2005). Determination of selenium in nutritionally relevant foods by graphite furnace atomic absorption spectrometry using arsenic as internal standard, Food Chemistry, 93(2), November 2005, 355-360. https://doi.org/10.1016/j.foodchem.2004.11.024

Onianwa, P. C., Adetola, I. G., Iwegbue, C. M. A., Ojo, M. F., \& Tella, O. O. (1999). Trace heavy metals of some Nigerian beverages and food drinks, Food Chemistry, 66(3), 275-279. 
https://doi.org/10.1016/S0308-8146(98)00257-X

Paula, F. J. A., Guiné, R. P. F., \& Cruz-lopes, L. (2015). Effects of pre- and post-harvest factors on the selected elements contents in fruit juices, Czech Journal of Food Science., 33, 384-391. http://hdl.handle.net/10773/18002. https://doi.org/10.17221/531/2014-CJFS

Perez, A. L., Smith, B. W., \& Anderson, K. A. (2006). Stable isotope and trace element profiling combined with classification models to differentiate geographic growing origin for three fruits: Effects of Subregion and Variety, Journal of Agricultural and Food Chemistry, 54, 4506-4516. https://doi.org/10.1021/jf0600455

Santos Froes, R. E., Neto, W. B., Silva, N. O. C. E., Lopes Pereira Naveira, R., Nascentes, C. C., \& da Silva J. B. B. (2009). Multivariate optimization by exploratory analysis applied to the determination of microelements in fruit juice by inductively coupled plasma optical emission spectrometry, Spectrochimica Acta, Part B 64, 619-622. https://doi.org/10.1016/j.sab.2009.06.006

Simpkins, W. A., Louie, H., Wu, M., Harrison, M., \& Goldberg, D. (2000). Trace elements in Australian orange juices and other products, Food Chem. 71, 423-433. https://doi.org/10.1016/S0308-8146(00)00150-3

Szymczycha-Madeja, A., \& Welna, M. (2013). Evaluation of a simple and fast method for the multi-elemental analysis in commercial fruit juice samples using atomic emission spectrometry, Food Chemistry, 141, 3466-3472. https://doi.org/10.1016/j.foodchem.2013.06.067

Szymczycha-Madeja, A., Welna, M., Jedryczko, D., \& Pohl, P. (2014). Developments and strategies in the spectrochemical elemental analysis of fruit juices, Trends in Analytical Chemistry, 55, 68-80. https://doi.org/10.1016/j.trac.2013.12.005

Tormen, L., Torres, D. P., Dittert, I. M., Arau' jo, R. G. O., Frescura, V. L. A., \& Jose, C. A. (2011). Rapid assessment of metal contamination in commercial fruit juices by inductively coupled mass spectrometry after a simple dilution, Journal of Food Composition and Analysis, 24, 95-102. https://doi.org/10.1016/j.jfca.2010.06.004

Tufuor, J. K., Bentum, J. K., Essumang, D. K., \& Koranteng-Addo, J. E. (2011). Analysis of heavy metals in citrus juice from the Abura-Asebu-Kwamankese district, Ghana, Journal of Chemical and Pharmaceutical Research (ISSN: 0975-7384), 3, 397-402.

Williams, A. B., Ayejuyo, O. O., \& Ogunyale, A. F. (2009). Trace metal levels in fruit juices and carbonated beverages in Nigeria, Environmental Monitoring and Assessment, 156, 303-306. https://doi.org/10.1007/s10661-008-0485-1

World Health Organization (WHO). (1996). Trace Elements in human nutrition and health

World Health Organization (WHO). (2006). Les lignes directrice de l'OMS en ce qui concerne la qualité de l'eau potable. (Http://www.lenntech.fr/periodique/elements/)

World Health Organization WHO. (1972). Expert Committee on Trace Metals in Human Nutrition. World Health

\section{Copyrights}

Copyright for this article is retained by the author(s), with first publication rights granted to the journal.

This is an open-access article distributed under the terms and conditions of the Creative Commons Attribution license (http://creativecommons.org/licenses/by/4.0/). 